\title{
Permakultura a teorie environmentální výchovy (EV): mapující přehledová studie
}

\author{
Monika Janáková \\ Envigogika 12 (1) - Recenzované články/ Reviewed Papers
}

Published/ Publikováno 25. 11. 2016

DOI: $\underline{10.14712 / 18023061.529}$

\begin{abstract}
Abstrakt
Text se věnuje konceptu permakultury ve vztahu k etablovaným teoriím environmentální výchovy (EV). Přehledová studie je založena na výzkumu přibližně 400 textů $z$ domácích i zahraničních zdrojů. Texty byly vyhledávány pomocí klíčových slov: environmentální výchova/vzdělávání (teorie, dějiny, hodnoty), permakultura, výchova k ochraně př́rody, výchova k péči o životní prostředí, ekologická výchova, globální výchova, udržitelný rozvoj, člověk a životní prostředí (české zdroje); teorie EV, permakultura (zahraniční zdroje). $V$ textu je pro zasazení konceptu permakultury do teorií EV využita vlastní typologie teorií EV (mikroteorie, teorie středního dosahu, makroteorie, abstraktní filosofické a etické teorie). Hlavním zjištěním je, že permakultura jako koncept se nachází na periferii teoretických diskusí EV. Je prozatím spíše nástrojem praktické EV (nejčastěji v podobě metodik uvádějící návody pedagogického využití zahrady v rámci EV), než součástí teorie EV. Podobnost permakulturního konceptu byla nalezena zejména s globální výchovou a teoriemi místně zakotveného učení a zkušenostního učení. Celkově však permakultura není dostatečně sofistikovaným teoretickým konceptem, ale má teoretický potenciál. Její postavení vzhledem $\mathrm{k}$ současným dominantním teoriím EV je spíše marginální. $\mathrm{V}$ tomto ohledu permakultura představuje výzvu pro teoretický výzkum v pedagogických vědách.
\end{abstract}

\section{Klíčová slova}

environmentální výchova; permakultura

\begin{abstract}
The text deals with the concept of permaculture in the context of environmental education (EE). It shows the position of permaculture as a concept in the context of established theories of EE. The review is based on library research of approximately 400 texts from Czech and foreign library sources. The texts were chosen based on the following key words: environmental education (theory, values, and history), permaculture education, global education, education for environmental protection, education for the sustainable development (Czech sources); theory of environmental education, permaculture (foreign sources). A typology arising from this work is used to embed permaculture into EE theories
\end{abstract}


(micro-theories, medium-range theories, macrotheories and philosophical and ethical theories) and is used in the text for framing the concept in the field. The main finding is that permaculture as a concept lies on the periphery of theoretical discussions in $E E$, and at the moment is more of a tool of practical EE (mostly in the form of manuals for using gardens in EE) rather than a component of EE theory. The biggest overlap is between permaculture and global education and theories of place based education and experience based education. In general, permaculture is not a sufficiently sophisticated theoretical concept, but it has theoretical potential. In this respect permaculture is a challenge for theoretical research in educational sciences.

\section{Key words}

Environmental education; permaculture 


\section{1. Úvod}

Hlavní výzkumná otázka badatelského projektu, jehož součástí je předkládaná přehledová studie, zní: Do jaké míry může permakultura sloužit jako základní nosný koncept a systematický rámec environmentální výchovy? Výzkumný design projektu ve stávající podobě počítá s realizací dvou částí výzkumu. $V$ teoretické rovině půjde o analýzu konceptu permakultury s cílem ukázat realisticky místo, potenciál i limity permakulturního prístupu v kontextu teoretického zázemí environmentální výchovy. V návaznosti na tuto konceptuální analýzu bude empirický výzkum s prvky tzv. akčního výzkumu zkoumat možnosti tvorby a systematického využití permakulturní zahrady a permakulturně orientovaného výchovně-vzdělávacího programu jako dvou nástrojů environmentální výchovy.

Cílem předkládaného textu je vytvořit znalostní zázemí pro řešení první teoretické části výzkumu v podobě zodpovězení dílčí podotázky: Jaké je postavení permakultury jako konceptu vzhledem k etablovaným teoriím environmentální výchovy?

Protože výzkumný projekt se snaží nalézt most mezi oblastmi vědy, které nejsou standardně spojovány (pedagogika, zemědělství), ještě předtím, než budou představeny hlavní zjištění studia literatury, shrne úvodní část základní informace o permakulturních principech a načrtne předpokládané spojení s tou oblastí pedagogické vědy, která se vztahuje k environmentální výchově. Tyto předpoklady jsou zároveň orientačními body pro vyhledávání relevantní literatury a informačních zdrojů. Jsou tak určující pro členění podkapitoly shrnující výsledky analýzy literatury, která představuje třetí část studie. Protože oblast environmentální výchovy představuje široké interdisciplinární pole s množstvím informačních zdrojů a proto, že základní výzkumná otázka je formulována poměrně široce, odborná literatura i informační zdroje k tématu se zdají být téměř „nekonečné". Z tohoto důvodu druhá část studie představuje metodu, pomocí níž bylo vyhledávání zdrojů pro přehled provedeno včetně reflexe jejích heuristických omezení. Třetí část studie přináší přehled hlavních poznatků umožňujících zasadit koncept permakultury do souřadnic teoretické výbavy environmentální výchovy a na ni navázaných oblastí environmentální filosofie, sociologie a etiky. Závěrečná čtvrtá část studie shrnuje hlavní zjištění a diskutuje je s ohledem na potřeby dalšího směřování výzkumu.

\section{Permakultura a pedagogická věda}

Pedagogické texty se shodují jak v tom, že environmentální výchova patři mezi přední témata pedagogiky 21. století (Horká in Průcha, 2009b, s. 852-856; Hutchinson, 1996), tak v tom, že kladou důraz na využití pobytu v přírodním prostředí, nejčastěji zahradě (např. Moore 1995, Williams, Brown 2012) a tzv. zkušenostní či zážitkovou výuku. ${ }^{1}$ Environmentální výchova tvoří aktuální samostatnou tematickou podoblast pedagogického výzkumu i praxe (srov. Horká 2005, Činčera 2007, 2013a, 2013b, 2013c,. Máchal 2007, Leblová 2012, Schovajsová 2010 atd.) disponující i vlastními vědeckými časopisy (Environmental Education Research, Journal of Environmental Education, česká Envigogika).

Permakultura jako koncept byla sestavena v 70. letech 20. století v Austrálii a jejími autory jsou Bill Mollison a David Holmgren. K nám začala pronikat v 90 . letech téhož století včetně relativně nedávných překladů (Holmgren 2006, Mollison 2012). Představuje vytvá-

\footnotetext{
${ }^{1}$ Tzv. experience-based education, (Lewis \& Mansfield \& Baudains 2008), podle typologie českých autorů má k tomu nejbliže asi dovednostně-praktická metoda (Maňák, Švec 2003, s. 91-104).
} 
ření trvale udržitelných systémü² ${ }^{2}$ jež jsou využívány nejen pro potravinové samozásobitelství, ale i jako cesta $k$ soběstačnosti obecně. Může se jednat o soběstačnost potravinovou, energetickou ${ }^{3}$, finanční, apod.

Permakultura je holistickým systémem dotýkající se mnoha oblastí života. Zakladatel "evropské" permakultury Declan Kennedy hovoří o tom, že podle něj se pojem permakultura rozšíril z pưvodního „permanentního zemědělství" či biopěstitelství na celý životní styl. $Z$ hlediska environmentální výchovy je podstatné, že $v$ základu permakultury stojí etika a to etika environmentální, jež uznává hodnotu každé živé věci samu o sobě. Permakultura není zdaleka jen zahradnickou vědou, není jen naukou o způsobu jak se docílit ideálu udržitelného života. Je světonázorem, etickým systémem. ${ }^{4} \mathrm{Z}$ permakulturní etiky celý koncept permakultury vychází, na něj navazuje a z něj se rozvíjí její podoba a cíle. Permakulturní etika má tři základní body. Tím prvním je "Péče o zemi" ${ }^{5}$, druhým "Péče o lidi" ${ }^{6}$ a třetím "Omezení populace a spotřeby". Permakulturní etika má ambice prostoupit všemi stránkami životního prostředí, společnosti i ekonomických systémů (Mollison, 2012, s. 3). Permakulturní teorie i praxe se kryjí s požadavky environmentální i globální výchovy, jako je např.: zamezení devastace životního prostředí, pěstování úcty k životu, rozhodování v duchu ekologické etiky a principů trvalé udržitelnosti, vzdělávání v souvislostech, důraz na propojenost člověka, kultury a přírody, prosazování zkušenostního pojetí učení (Horká, 2000, s. 47-52). Permakulturní etiku Ize ztotožnit s ekologickými aspekty globální výchovy ( $v$ našem prostředí se tématu globální výchovy věnuje např. H. Horká, ze zahraničních autorů Ize uvést. D. Selbyho a G. Pikea). Stejně jako ekologické aspekty mají prostoupit všemi prvky globální výchovy (tj. obsahem), tak permakulturní etika má prostoupit všechny aspekty lidské činnosti. Za klíčový se označuje systémový př́stup, nahrazení konkurence spoluprací (kooperace), decentralizace, budování "zespodu nahoru", tvořivé myšlení, úcta k druhým i sobě, schopnost soužití s druhými (důraz na komunitu), odpovědnost, schopnost tvořivě řešit problémy atd. (Mollison, 2012, s. 3). Zde se permakulturní pojetí přístupu ke světu nápadně kryje s doporučeními mezinárodní komisí UNESCO „Vzdělávání pro 21. stol." z roku 1993 (Horká, 2000, s. 14) ${ }^{7}$. Permakultura, podobně jako globální výchova a ekosociální teorie vzdělávání (Bertrand, 1998), má za cíl (skrze design - promyš-

\footnotetext{
${ }^{2}$ Zde záměrně používáme termín „trvale" udržitelný systém, nebot' se vyskytuje v publikacích předních představitelů permakultury jako je např. Bill Mollison. Zároveň sám pojem „permakultura (angl.. permaculture)" vznikl spojením anglických slov permanent a agriculture. Je to koncept poprvé formulovaný v 70. letech 20 . století v kontextu trvale udržitelného zemědělství, ale již tehdy s ambicí budování trvale udržitelné kultury obecně. Nejen tedy "permanent agriculture", ale zároveň znamená i snahu o "permanent culture".

${ }^{3}$ Permakultura pracuje s teorií ropného zlomu a jejím cílem je tedy člověk nezávislý na fosilních palivech.

${ }^{4}$ Jeden ze zakladatelů permakultury D. Holmgren (2006) o sobě píše: „Jsem hrdý na svou ateistickou výchovu, v niž humanistické hodnoty zformovaly etický rámec racionálního světonázoru".

5 Péče o zemi (o přírodu) spočívá v zajištění ochrany ekosystému tak, aby jeho činnost nebyla ohrožena. Právě permakultura nabízí mnohá řešení, jak boj proti přírodě a jejímu ničení nahradit spoluprací s prírodou a jak obnovovat poškozené ekosystémy.

${ }^{6}$ Péče o lidi spočivá v zajištění jejich životních potřeb, jako je voda, potrava, přístřeší, ošacení a podobně. Člověk však není, podle permakultury, jen konzument, potřebuje také praktické a smysluplné životní vzdělávání, smysluplnou a naplňující práci, možnost seberealizace a budování vlastního zázemí a přátelské mezilidské vztahy. Těmto oblastem se permakultura aktivně věnuje a snaží se pro ně hledat vhodná řešení.

${ }^{7}$ Vznikla zde doporučení 4 pilírů vzdělávání: učit se jednat (tvořivě zasahovat), učit se být (rozvoj osobnosti), učit se poznávat (myslet) a učit se žít společně s ostatními (spolupráce, komunikace...).
} 
lené a poučené navrhování po vzoru prírody) vytvořit ekologicky zdravé a ekonomicky prosperující systémy, jež jsou schopny zabezpečit své potřeby bez ničení prírody a tím se stát také dlouhodobě udržitelnými. J. Svoboda, jeden z propagátorů permakultury v Česku, ji označuje za "malou revoluci" a shrnuje permakulturu jako zodpovědný př́stup ke světu, tvořivý způsob myšlení založený na pozorování. Je uvědomělým designem měnící současné destruktivní formy, jimiž lidstvo zajištúuje své potřeby a využíá naši planetu, za způsoby planetě i lidem prospívající. Etické principy permakultury zůstávají stejné na celém světě, mění se použité techniky (Svoboda, 2009, s. 10).

S vědomím nutnosti kritického odstupu ke všem revolucím zůstává zdrojem „badatelského optimismu" $v$ pokusu o systematičtější aplikaci permakulturních principů v rovině pedagogické teorie i praxe skutečnost, že se koncept již osvědčil, tj. prokázal svoji funkčnost $v$ různých oblastech. Permakulturní design (navrhování dlouhodobě udržitelných systémů) má dva základní kroky (Mollison, 2012, s. 5). Ten první se věnuje zákonům a principům (idejím), jež Ize přizpůsobit jakýmkoliv klimatickým a kulturním podmínkám (takže je Ize označit jako globální principy $)^{8}$, tento krok je v rovině teorie, zatímco $v$ druhém kroku jde o praktické techniky (návody), jež jsou v různých podmínkách a kulturách odlišné (ty Ize označit jako principy pro lokální použití). Podle zastánců permakultury Ize využíváním a kombinací těchto dvou kroků docílit funkčních, trvale udržitelných systémů. Dosáhne se tím stav, jež Ize připodobnit termínu "globální multikultura", jež můžeme najít u H. Horké (2000, s. 60), kdy se nebude jednat o unifikovanou kulturu, ale o soubor kultur uchovávajících si místní kulturní tradici.

Permakulturní přístup v současné době stále dominuje především snaze o trvale udržitelné zemědělství a $z$ této oblasti pochází převážná většina odborné literatury a výzkumných projektů, včetně těch, které spadají do oblasti pedagogických věd ( $v$ této oblasti jsou typické projekty studentských farem, resp. úpravy školních areálů středních a vysokých škol v USA na kterých aktivně participují samotní studenti). Potenciál permakulturního přístupu se však zdá být větší a předkládaný projekt si klade za cíl zjistit možnosti a limity jeho systematičtější aplikace na poli environmentální výchovy. $K$ tomuto postoji vede navrhovatelku zjištění, že $v$ permakulturním př́stupu Ize rozlišit tři roviny: 1. Permakultura vystupuje jako abstraktní světonázor a hodnotový systém pro udržitelný rozvoj (Holmgren, Mollison ad.) 2. Permakulturní principy nachází svoji aplikaci v rovině formování sociálních vztahů (terapie, pedagogické poradenství, koučink). (viz např. J. Froněk 2012, nebo psychologicko-pedagogické přednášky Tatiany Brodské $s$ názvem Líně a šetrně) 3. Permakulturní přístup nachází své uplatnění při úpravách školních zahrad.

$\mathrm{Na}$ základě těchto úvah jsem teoretickou výzkumnou podotázku projektu - Jaké je postavení permakultury jako konceptu vzhledem k etablovaným teoriím environmentální výchovy ${ }^{9}(\mathrm{EV})$ ? - pro účely této studie rozvedla do těchto podotázek: Do jaké míry a ja-

\footnotetext{
${ }^{8}$ Sem patří zejména: 1 ) Relativní umístění (každý prvek je umístěn ve vzájemném vztahu k ostatním); 2) Každý prvek vykonává více funkcí; 3)Každá důležitá funkce je zabezpečována mnohými prvky; 4) Energeticky úsporné plánování (zónování, výškové plánování); 5) Dává se přednost biologickým zdrojům před fosilními palivy (využívání obnovitelných zdrojů); 6) Koloběh energie přímo na místě (jak paliv, tak lidské energie); 7) Využívání zrychlené přírodní sukcese; 8) Využívání polykultur a diverzity (různorodosti, rozmanitosti) vzájemně si prospěšných druhů v rámci systému; 9 ) $\mathrm{K}$ dosažení nejlepších výsledků se využívají okrajové efekty a přírodní vzory; 10)Využíaání malých a pomalých řešení; 11) Dání přednosti začleňování před oddělováním; 12) Usměrňování sama sebe a přijímání zpětné vazby; 13) Pozoruj a jednej.

${ }^{9} \mathrm{~V}$ tomto textu dáváme závěrně přednost pojmu environmentální výchova (EV), před environmentální výchova a vzdělávání (EVV). Jsme si vědomi, že termín EVV se používá například ve strategiích (viz
} 
kým způsobem se s pojmem permakultura pracuje $v$ kontextu specializovaných publikací $\mathrm{k}$ teorii EV? Jaké teorie EV dominují? Jaké je skutečné a možné místo permakultury $v$ tomto spektru? Před popisem výsledků však představíme způsob, jakým byla provedena rešerše různých informačních zdrojů.

\section{Metoda výběru}

Jak bylo zmíněno $v$ úvodu, informačních zdrojů a specializovaných publikací k tématu environmentální výchovy je nepřeberné množství, zahrnující spektrum rozprostřené od abstraktních filosofických úvah, přes specializované monografie, encyklopedické publikace a vědecké články, až po prakticky pojaté příručky pro pedagogy nebo dokumenty vzdělávacích institucí různých úrovní počínaje rozsáhlými dokumenty ministerstva školství a konče vzdělávacími programy lesních školek nebo brožurkami středisek ekologické výchovy. $Z$ tohoto množství textů různé kvality i rozsahu je třeba uskutečnit výběr. Ačkoli existují různé návody jak postupovat (např. Spousta, 2003; Mareš, 2013; Šanderová, 2009, s. 76), každé téma je natolik specifické, že je třeba vždy znovu vymyslet konkrétní postup (metodu) výběru textů.

\section{Domácí zdroje}

Využila jsem domácí i zahraniční zdroje. Pro rešerši domácích zdrojů jsem zaprvé zpracovala přehled s pomocí odborné pracovnice knihovny Pedagogické fakulty MU a za druhé jsem tematicky zpracovala český specializovaný časopis Envigogika, který je publikován on-line a umožňuje tzv. fulltextové prohledávání. Přehled z knihovny byl vytvořen podle klíčových slov $v$ češtině $i$ angličtině: environmentální výchova/vzdělávání (teorie, dějiny, hodnoty), permakultura, výchova k ochraně prírody, výchova k péči o životní prostředí, ekologická výchova, globální výchova, udržitelný rozvoj, člověk a životní prostředí. Anglické ekvivalenty: environmental education (theory, values, history), global education, education for the relation to nature, education for environmental protection, education for the sustainable development. Časové vymezení záznamů bylo stanoveno od roku 1900 do roku 2015. Zdroje byly omezeny na odborné články, knihy, internetové odkazy, Souborný katalog Masarykovy univerzity, Archiv závěrečných prací na MU, MZK - katalog Moravské zemské knihovny v Brně, CASLIN - Souborný katalog České republiky, ANL - Články v českých novinách, časopisech a sbornících, Ebsco. Výsledkem byl seznam 260 publikací.

V druhé fázi jsem zpracovala články hlavního (a jediného) českého časopisu specializovaného na environmentální výchovu Envigogika od jeho počátků, tj. od roku 2006 do současnosti tj. do roku 2015, resp. do 2 . čísla roku 2015, protože ostatní dvě čísla nebyla $\checkmark$ době psaní studie dostupná na internetu. Výběr článků jsem provedla jednak na základě klíčových slov (udržitelný rozvoj, environmentální etika, environmentální vzdělávání, environmentální výchova, etika, evaluace, vzdělávání pro udržitelný rozvoj, permakultura, teorie environmentální výchovy) a dále podle názvů v souhrnném seznamu článků časopisu. Ke každému článku jsem přečetla abstrakt a $v$ př́padě, že informace $v$ abstraktu ukázaly na užší souvislost se zkoumaným tématem, jsem zpracovala tzv. informativním čte-

například Broukalová, L. (2011). Cíle a indikátory pro environmentální vzdělávání, výchovu a osvětu v České republice. Praha: Ministerstvo životního prostředí České republiky. Dostupné z:

http://www.mzp.cz/cz/cile_indikatory_evvo_dokument), nebo i některých metodikách. Avšak výchova v našem pojetí zahrnuje v sobě organicky i vzdělávání. Proto, pakliže řekneme environmentální výchova, myslíme tím samožrejmě i environmentální vzdělávání. 
ním (Šanderová, 2009, s. 37) rychle celý článek. Výsledkem byl soupis 52 časopiseckých textů, převážně studií, ale také recenzních statí a diskusních příspěvků.

\section{Zahraniční zdroje}

Ze zahraničních zdrojů pro výběr jsem zvolila kombinaci prohledávání katalogu britské London School of Economics (LSE) a dvou hlavních oborových časopisů Journal of Environmental Education (JEE) a Environmental Education Research (EER). Zdroje londýnské knihovny LSE jsem zvolila $z$ důvodů relativní dostupnosti. LSE je jednou z největších z Brna relativně dostupných světových knihoven specializovaných na oblast sociálních věd. JEE představuje pravděpodobně hlavní mezinárodní časopis pro oblast environmentální výchovy vycházející téměř půl století. Seznámení s jeho obsahem by mělo přinést určitou celkovou znalost o tom, co se v oblasti environmentální výchovy děje $v$ celosvětovém měřítku. $E E R$ vychází přes dvacet let a tvoří asi druhé mezinárodně důležité fórum pro výzkum v oblasti environmentálního vzdělávání a výchovy.

Odborné texty $v$ londýnské knihovně jsem vyhledala podle předmětových hesel "theory of environmental education", „permaculture". Následně jsem prošla zhruba prvních 250 bibliografických odkazů seřazených podle relevance $\mathrm{k}$ heslům odkazujícím na teorii environmentálních vzdělání a všech 50 citací, které se vztahují k heslu permaculture. Z těchto citací jsem pro účely přehledové studie vybrala texty podle názvu a s ohledem na dostupnost on-line, tj. možnost získání ke studiu domů. Protože jejich největší podíl byl ve dvou uvedených časopisech a dále v časopise Educational Philosophy and Theory (EPT), rozhodla jsem se omezit výběr na tyto informační zdroje, mj. s ohledem na reálné možnosti získání textů.

Specializované časopisy JEE a EER, které reprezentují centra mezinárodní vědecké debaty $v$ oblasti environmentálního výchovy, jsem však prošla ještě dvojím způsobem. Protože mi jde o zasazení konceptu permakultury do kontextu dominujících teoretických konceptů v oblasti environmentální výchovy, z obou časopisů (JEE, EER) jsem vybrala 20 nejčtenějších článků, které by měly do značné míry odrážet klíčová témata a koncepty příslušné podoblasti pedagogického výzkumu. Časopis JEE, který vychází delší dobu, jsem si navíc prošla po ročnících od r. 2009 do současnosti a vybrala texty, které mne zaujaly názvem a abstraktem $\mathrm{s}$ ohledem na celkové téma práce (zaměření na teoretičtější texty, texty $\mathrm{k}$ environmentální výchově $v$ raném dětství a $v$ primárním školství, zahradám a dětskému zahradničení). Soubor takto vybraných článků obsahuje 90 studií ze tří nejdůležitějších oborových časopisů. ${ }^{10}$

Takto získaný široký soupis přibližně 400 domácích i zahraničních publikací ( $260 \mathrm{z}$ rešerše odborné knihovnice pedagogické fakulty +52 česká Envigogigka +90 zahraniční časopisy + zahraniční časopisy + nahodilé texty) jsem roztř́dila v prvním kroku podle názvu do několika induktivně vytvořených kategorií:

- Hodnoty a environmentální hodnoty

- Teorie hodnot

- Permakulturní zahradnictví. Př́rodní zahrady

\footnotetext{
${ }^{10}$ Za jejich získání na LSE a dovezení z Londýna, a také za pomoc při jejich zpracování a porozumění děkuji M. Kudělovi a D. Janákovi.
} 
- Permakultura a její principy, permakultura a výchova, permakultura a společnost, kultura, filozofie

- Enviro výchova obecně. Její principy, obsah, cíle, historie

- Enviro výchova prakticky-návody, metodiky

- Filozofie prírody. Př́roda a kultura

- Teorie výchovy

- Ochrana prírody - praktická

- Globální výchova, Výchova pro 21. století

- Environment historie a environment obecně

- Ostatní

Uvedené kategorie přihlízí k rozdílu mezi teorií (konceptuální analýzy), empirickým výzkumem a praxí (metodiky) i mezi pedagogickou (výuka, výchova) a mimopedagogickou rovinou problematiky (ochrana př́rody, zemědělství), které se ve výzkumném projektu prolínají. Uvedený seznam kategorií je spíše pracovní verzí členění umožňující rychlejší orientaci v poměrně rozsáhlém souboru textů.

Následně jsem z podskupin teoretičtějších textů vybírala pomocí názvů nejslibnější práce z pohledu zaměření studie, ke kterým jsem procházela abstrakty a anotace, př́ležitostně prošla informativním čtením, tj. zpracovala jsem je stejným způsobem, jako texty v časopise Envigogika. Tímto užším sítem prošlo přibližně 150 textů, ze kterých vychází výsledný přehled. Oporou mi byly pochopitelně také relevantní texty, které jsem znala již dřive anebo je nalezla bez pomoci popsaných postupů. Existence takových prací ukazuje na meze zvolené metody, tj. že nezachytí vše, i když pravděpodobně většinu podstatného. Druhé omezení je technického typu. Ze seznamu vytvořeného za pomoci knihovníků nebylo možné mít $v$ době psaní přehledu $k$ dispozici všechny vybrané texty. Řada knižních publikací není on-line ani dostupná v brněnských knihovnách. Na druhou stranu, protože $v$ drtivé většině př́padů jde o novou literaturu, alespoň určitou informaci v podobě anotace, ukázky, abstraktu či obsahu je možné téměř ke všem publikacím najít. Vzhledem $k$ těmto omezením, má uskutečněný přehled hodnotu tzv. systematického mapujícího přehledu (Mareš, 2013, s. 430).

\section{Výsledky}

Podle vymezení J. Prokopa v Pedagogické encyklopedii "teoriemi rozumíme skupinu nebo soubor obecných koncepcí či předpokladů, které objasňují fungování institucí ( $v$ našem př́ipadě především školy), nebo objasňují průběh procesů ( $v$ našem případě je to vyučování a učení). Přitom tyto koncepce a předpoklady musí být dostatečně abstraktní, aby je bylo možné přenést a uplatnit rovněž $v$ jiných situacích než těch, které posloužili $k$ jejich formulaci." (Prokop in Průcha 2009b, s. 661) Podle citovaného autora jsou předmětem teorie výchovy "různé teorie, směry a výchovné ideologie poskytující radu teoretických modelů a způsobů myšlení o výchovném procesu." (ibid.). Prokop rozlišuje v zásadě dva typy těchto teorií: První typ tvoří teorie výchovy pojaté převážně jako filosofická disciplína, druhý typ představují empiricky založené teorie výchovy (ibid.). Ideologický aspekt teorií 
výchovy je obsažený především v teoriích prvního typu, tj. ve filosofických teoriích výchovy, ale v menší míře je prítomný i v empiricky založených teoriích jako jakýsi hodnotový horizont smyslu výchovy. Filosofické teorie výchovy jsou často odvozeny z větších a komplexnějších filosofických systémů a případ environmentální výchovy to také dokládá. Ideologickému tj. hodnotově zakotvenému a hodnotícímu aspektu pedagogické teorie věnují zvláštní pozornost také další systematici teorie výchovy. V. Štverák ve svém díle z obecné a srovnávací pedagogiky vyčleňuje otázce formulace cílů výchovy samostatnou kapitolu, přičemž jeho zájmem není ani tak definice nějakých pedagogických cílů, jako spiš přehled základních kritérií, podle kterých jsou v různých pedagogických přistupech tyto cíle formulovány (srov. Štverák 1999, s. 45-55). V poměrně nedávné monografické publikaci $M$. Strouhala $\mathrm{k}$ teorii výchovy tvoři napětí mezi hodnotícím a nehodnotícím rozměrem této pedagogické disciplíny ztotožňované s napětím mezi filosofickým a vědeckým výkladem dokonce hlavní osu celého pojednání (Strouhal, 2013).

Aplikujeme-li na hodnotový horizont environmentální výchovy typologii soudobých teorií vzdělávání Y. Bertranda, pak teorie environmentální výchovy přináleží mezi tzv. sociální teorie. Je pro ně typické, že "se opírají o princip, že vzdělání má umožnit řešení problémů sociálních a kulturních i problému životního prostředí." (Bertrand, 1998, s. 18) Podle Y. Bertranda se autoři z oblasti těchto teorií zaměřují na otázky sociálních nerovnost, segregaci, elitářství, problémy životního prostředí, negativní vliv technologií a průmyslu na kvalitu života na Zemi. Cílem vzdělání je príprava žáků na řešení těchto problémů. Samotný Bertrand se explicitně přiklání právě k tomuto typu teorií a př́značné je, že svoji knihu končí angažovanou kapitolkou "Za novou ekosociální kompetenci" (Bertrand, 1998, s. 227228). ${ }^{11} \mathrm{O}$ tom, že ekologická výchova ${ }^{12}$ patří mezi důležité typy teoretických směrů soudobé pedagogiky, svědčí rozsáhlá pedagogická systematizace polských autorů Kwiecinskeho a Sliwerskeho z roku 2004 (Prokop in Průcha, 2009b, s. 665), kteří tzv. ekologickou pedagogiku řadí mezi třináct hlavních proudů soudobé pedagogické reflexe. ${ }^{13} \mathrm{O}$ významnosti environmentální výchovy hovoří také v českém kontextu poměrně rozsáhlé heslo $\mathrm{H}$. Horké ve svazku Pedagogické encyklopedie (Horká in Průcha, 2009, s. 852-856) a také její zařazení mezi prưřezová témata v RVP ZV.

S využitím uvedených teorií o teoriích, tj. meta-teorií, můžeme rozčlenit soubor porovnávaných textů podle míry obecnosti (empirické vs. filosofické teorie) do čtyř typů, které jsem si pracovně nazvala takto: 1 . mikroteorie jsou teoriemi zaměřenými na postupy a návody předávání poznatků, 2 . teorie středního dosahu ${ }^{14}$, 3. teorie rámující EV celospo-

\footnotetext{
${ }^{11}$ Bertrandova typologie obsahuje celkově sedm typů či proudů teorií vzdělávání. Kromě sociálních teorií to jsou spiritualistické teorie, personalistické teorie, kognitivně psychologické teorie, technologické teorie, sociokognitivní a akademické teorie.

${ }^{12}$ Autorka této přehledové studie sama dává přednost termínu environmentální výchova před ekologickou výchovou. Nebot ekologickou výchovu chápe více přírodovědně zaměřenou, zatímco environmentální výchova má v sobě více akcentovány aspekty humanistické. Avšak pokud autor citovaného textu, tak jak je tomu v tomto případě, používá pojem ekologická výchova, používá jej v daném kontextu autorka také.

${ }^{13}$ Syntetická práce polských autorů o současných pedagogických proudech a směrech představuje: pozitivistickou pedagogiku, pedagogiku kultury, personalistickou, existenciální, náboženskou, tzv. novou výchovu, kritickou pedagogiku, antiautoritativní, emancipační, interkulturní, ekologickou, negativní, postmoderní (Kwiecinski \& Sliwerski 2004, cit. dle Prokop 2009: 665)

${ }_{14}$ Pojem teorie středního dosahu je inspirován Mertonovým pojmem v souladu s interpretací konceptu teorie středního dosahu jako teorie vysvětlující určitou omezenou oblast jevů (Zich 1996: 1313), v našem případě environmentální výchovy. Mertonova koncepce byla motivována především obhajobou plurality $v$ oblasti sociologické teorie (Merton 2010: 66-116, zejm. 90, 94, 97).
} 
lečensky a globálně, 4. abstraktní filosofické a etické koncepce. Uvedené čtyři stupně abstrakce a šíre záběru profiluji i odlišné oblasti zájmu, ačkoli hranice mezi nimi nejsou nepropustné a $v$ textech se témata i úrovně často prolínají, a to především $v$ knižních přehledových publikacích. Kritériem pro zařazení konkrétního textu do jedné ze čtyř kategorií byla převládající charakteristika textu identifikovaná autorkou při jeho četbě. Přitom hlavním dělícím kritériem mezi texty první a druhé kategorie bylo zodpovězení otázky, zda se jedná o koncept řešící určitý problému uvnitř EV, nebo zda nabízí pohled na EV jako celek. Dělítkem mezi druhou a třetí kategorií bylo rozřešení otázky, zda konceptualizace EV je cílena na rovinu pedagogického procesu, nebo zda jde spíše o tematizaci vzdělání jako takového $\checkmark$ kontextu environmentálních problémů globalizovaného světa a celospolečenských souvislostí environmentálního vzdělání. Poslední čtvrtá oblast teorií se od makroteorií liší posunem těžiště reflexe EV od tematizace sociální funkce EV $\mathrm{k}$ její reflexi z pohledu ontologie nebo filosofické etiky.

\section{Mikroteorie EV}

Mikroteoriemi EV označuji teorie předávání poznatků, často metodicky zaměřené a teorie procesu proenvironmentálního jednání jednotlivců i skupin. Jsou to teorie nejvíce využitelné v didaktice EV, i když sami o sobě rámec didaktiky přesahují. Mikroteoriemi je označuji za prvé proto, že mají př́mý vztah $\mathrm{k}$ empirickému výzkumu a často jsou obsaženy ve studiích, které je testují empiricky, čímž je převádějí z obecnějších vod pedagogické teorie na pole EV. Tyto teorie jsou často na hraně mezi tím, co Ize nazvat empirickým výzkumem a teoretickým výzkumem. Snažila jsem se z těchto prací vybrat ty studie, které si berou za cíl skutečně otestovat teorii a tím ji rozšiřovat. Druhým důvodem je, že jsou to teorie konkrétního individuálního jednání, at už je to učení nebo chování šetrné k prírodě a životnímu prostředí. Mají tedy vztah $\mathrm{k}$ té nejkonkrétnější rovině vzdělávacího procesu. Mohou být přitom založeny ve velmi abstraktních představách o fungování lidské psychiky (např. Winter, 2009), nebo determinantách lidského jednání.

Do mikroteorí řadím také reflexe vztažené $\mathrm{k}$ procesu učení, roli učitele případně $\mathrm{i}$ rodičů a sociálního okolí, problematice hodnot apod., které nejsou založené na empirickém výzkumu ale spiše na odborné zkušenosti. Jejich ambicí ani není formulovat nějakou systematickou komplexnější teorii, tvoří jakési teoretické podhoubí či prostředí, a někdy i zárodky systematičtějších, větších teorií a jsou tak vskutku mikroteoriemi ve smyslu neempirického uchopení problematiky. Tento typ textů je $v$ reflexi EV četný. Pro účely přehledové studie je není nutné mapovat. Stěží je však Ize opominout a je třeba je zmínit alespoň jako určitý důležitý typ textů, charakteristický pro diskuse o $\mathrm{EV}$, nebot' to je zdaleka nejčastější typ teoretického uchopení $E V \vee$ textech věnovaných jak permakultuře a ekologickému zemědělství obecně, tak udržitelnému rozvoji, ochraně životního prostředí a globálním rizikům, nebo ekologické filosofii. Slovo teorie se však pro tyto různorodé reflexe zdá neadekvátní. Jsou to jakési teorie $v$ zárodku, a proto je řadím mezi mikroteorie.

Mikroteorie jsou zároveň výrazně nejrozsáhlejší oblastí teoretické reflexe environmentální výchovy. Pravděpodobně je tomu tak proto, že mají největší vztah k praxi (jednou ze zajímavých prací zabývajících se tématem propojení teorie a praxe je dílo $\mathrm{F}$. Korthagena a tzv. realistický model vyučováni ${ }^{15}$ ). Ostatně oblast metodických textů a vylo-

\footnotetext{
15 Tématu se věnuje Korthagenova kniha s názvem Jak spojit praxi s teorií: Didaktika realistického vzdělávání učitelů. Její shrnutí a kritické zhodnocení pak přináší např. studie otištěná v Pedagogické orientaci (Janík, Slavík, Najvar, Píšová 2012). Korthagen (2012) kritizuje tradiční pojetí učitelského vzdělávání založeného na modelu technické racionality. Jako efektivnější ve snaze o propojení teorie a
} 
ženě prakticky a/nebo výhradně empiricky pojatých prací je totiž zdaleka nejobsažnější oblastí publikační aktivity $v$ rámci EV (zde uved'me jako př́klad za všechny průkopnické popularizační práce biologa Karla Patočky $)^{16}$. Je přitom otázkou, jejiž zodpovězení překračuje hranice zájmu tohoto textu, zda se EV bez systematičtější teorie (teorií) může úspěšně dlouhodobě obejít nebo ne.

V oblasti mikroteorií můžeme nalézt jak snahy o teoretické zakotvení metodických postupů EV (např. Horká, 1996), tak meta-studie obsahující jak srovnávací analýzy různých teoretických př́stupů na vyšší úrovni obecnosti (např. Payne, 2002), nebo kritické vyrovnání s nimi (např. Dillon, 2003) upozorňující na občasné opomíjení teorií v EV výzkumu i na jednostrannou orientaci na školní proces na úkor neformálních forem vzdělání), reflexe toho, jak se vyvíjel výzkum $v$ oblasti EV a kam by bylo vhodné jej dál směřovat (Walker, 2006), nebo systematické pojednání o chybách v reflexi EV i jejím praktickém naplňování (Máchal, 2012, 2013). Určitou přehledovou ambici má uspořádání textů $\checkmark$ syntetické publikaci především severoamerických, britských a australských autorů o výzkumu $v$ oblasti $E V$, resp. $v$ její 5 . části věnované výzkumu výukového procesu $v$ EV (Stevenson \& Brody \& Dillon, Wals \& 2013, s. 243-288). Jak z této publikace, jejíz ambicí je podat jakýsi ucelený pohled na stav celého výzkumného pole $v$ oblasti $E V$, tak $z$ prehledu konkrétních studií a dílčích publikací je patrné, že v oblasti mikroteorií vystupují do popředí čtyři tematické oblastí zájmu.

Asi nejrozsáhlejší z nich tvoří teorie vztahů mezi vědomím a jednáním, teorie postojů. Rozsáhlou část tohoto zájmu tvoří různé modely pro-environmentálního chování a možnosti jeho ovlivnění výukou. Některé jsou založené na sofistikovaných kvantitativních empirických postupech (Liefländer, 2014; Schelly, Cross, Franzen, Hall, Reeve, 2012; Chao, 2012; Darner, 2012). Jejich výsledkem jsou různě složitá schémata a diagramy zachycující empiricky naměřené závislosti mezi jednotlivými proměnnými, které intervenují do formování environmentálních postojů a výsledného jednání. Výsledky těchto výzkumů slouží k navrhování a úpravám teoretických modelů funkcí výuky vzhledem k jednání. Jiné se zaměřují na osobu učitele (Vystrčil Marková \& Horká, 2013; Horáčková, 2015; Horká,

praxe navrhuje pro učitelské vzdělávání koncept tzv. realistické výuky, rozvíjeného v 80. letech 20. století ve výuce matematiky, kdy jsou matematické poznatky budovány na základě praktických zkušeností a problémů. Korthagen kritizuje i samotné pojetí teorie příznačné pro technickou racionalitu, na níž stojí tradiční učitelské vzdělávání.. Toto pojetí je reprezentováno Platónovým chápáním znalostí jako epistémé budující vědění jako strukturu obecných tvrzení pracujících s abstraktními pojmy a vztahy mezi nimi. "Tato struktura představuje teorii, která má - aplikovaná do konkrétního kontextu potenciál popisovat, vysvětlovat a predikovat fenomény reálného světa." (Janík, Slavík, Najvar, Píšová 2012). Avšak realistické učitelské vzdělávání stojí na straně Aristotelova přístupu ke znalosti jako fronésis. Vědění je praktickou moudrostí stavící své znalosti na konkrétních jednotlivostech a jejich kontextech. "Zatímco v tradičním modelu se postupuje od teorie skrze její aplikaci k praxi, $v$ realistickém modelu se jde cestou od praktických zkušeností k budování vlastních konceptuálních schémat, které osvětlují praxi a poskytují předpoklady spojiti s teorií." (Janík, Slavík, Najvar, Píšová 2012). Dalším důležitým pojmem, se kterým Korthagen pracuje, jsou gestalty, vnitřní entity určující chování učitele v různých situacích. Je to souhrn zájmů, potřeb, hodnot, významů, preferencí, pocitů a tendencí k jednání jedince. Tradiční učitelské vzdělávání neumí do těchto gestaltů proniknout a docílit, aby se přednášené teorie mohly stát součástí gestaltů a projevit se pak v učitelově praxi. Postupu od neuvědomovaných gestaltů k uvědomělému porozumění ( $\mathrm{k}$ jejich reflexi) říká Korthagen schematizace. "Prostřednictvím schematizace se u studentů učitelství utvářejí mentální struktury nové povahy, více kognitivní než afektivní, a více uvědomované." (Janík, Slavík, Najvar, Píšová 2012).

${ }^{16}$ RNDr. Karel Patočka narozen 2. 7. 1915 v Brně. Pracovník katedry př́rodopisu pedagogické fakulty, biolog. Popularizační práce v oboru: Náš les; Kouzla s rostlinami; Kouzla se zviŕaty; $V$ př́rodě se nenudím; Povídej mi sedmikrásko. 
1997; Kunz\& Shuman \& Ham, 1997; Karaarslan \& Ertepınar \& Sungur 2013; Pe'er \& Goldman \& Yavetz, 2007) a charakterizuje je spíše kvalitativní př́stup. Celkově je $\checkmark$ mikroteoriích EV jasný posun od znalostí $k$ dovednostem, konstatovaný již téměř před 20 lety (Jensen \& Schnack, 1997), který odpovídá výše uvedenému rámování teorií EV $\checkmark$ rámci Bertrandovi typologie a nechybí $\mathrm{i}$ studie $\mathrm{k}$ obecnějším kategoriím důležitým pro zkoumání environmentálních postojů jako je např. "environmentální senzitivita" (Chawla, 1998) apod. Nikoli bez zajímavosti je zjištění, že výzkum procesu učení se v oblasti EV téměř výlučně soustředí na institucionální rámec školy a spíše výjimkou (Leppänen \& Haahla \& Lensu \& Kuitunen, 2012; Green, 2015) je zkoumání těch nejpřirozenějších a zdaleka nejstarších forem učení $v$ rodině nebo komunitě, které jsou ve výzkumu EV spíše pozadím, prostředím, něčím vnějším, co se nechává pravděpodobně sociologům, psychologům a antropologům. Zda jsou príčiny tohoto stavu metodologické, -tj. jednoduše $v$ tom, že je daleko snadnější dělat výzkum ve škole, která má jasné hranice, jasně vymezené role, respondenti jsou roztř́děni a $v$ prípadě ochoty vedení školy $k$ výzkumu také snadno přesvědčeni $k$ participaci na výzkumu - nebo má uzavírání pedagogického výzkumu do institucionálních rámců škol a dalších vzdělávacích organizací nějaké hlubší prríčiny, jde mimo rámec této studie.

Samostatnou oblast zájmu představuje evaluace EV. Tato oblast se nepochybně konstituovala $v$ souvislosti s potřebami státní správy $v$ oblasti školství, ale i samotných aktérů edukace měřit a díky tomu nejen kontrolovat, ale i zvyšovat kvalitu školství ( $v$ těchto intencích viz např. Zelezny 1999). Nicméně celá podoblast se odvíjí od obecnějších definic smyslu a cíle $\mathrm{EV}$, čímž minimálně část prací z této oblasti překračuje rámec technických metodik směrem $\mathrm{k}$ teorii hledající smysl a význam EV a kladou si obecnější teoretickometodologické otázky. Mezi takovéto teoretičtěji zaměřené text Ize $v$ českém prostředí zařadit např. reflexe pojmů vzdělávací kvalita a kompetence J. Dlouhé (Dlouhá, 2009), nepřehlédnutelná je série studií J. Činčery (Činčera 2008a, 2008b, 2008c, 2009, 2011; Činčera \& Kulich \& Gollová, 2009; Činčera \& Gilar \& Sokolovičová, 2010), přičemž autor je zapojen jak do procesů tvorby vzdělávací politiky (viz Broukalová a kol. 2011), tak do konkrétních evaluací (např. Činčera, 2008b). Debata nad indikátory však zahrnuje daleko širší pole autorů, kteří např. na základě empirického výzkumu formulují požadavky na spojení evaluací EV s problematikou měření proměny postojů a hodnot (Janoušková \& Hák \& Maršák \& Pachmanová, 2010). Ze sledovaných zahraničních zdrojů vystupuje do popředí metodologická debata o celosvětově používané škále měření pro-environmentálních postojů, která vznikla v 70. letech (Dunlap \& Van Liere, 2008; Dunlap, 2008). Textů založených na empirické evaluaci, které obsahují menší nebo větší přesah $\mathrm{k}$ obecnějším otázkám cílů a smyslu EV, je nepočítaně.

Velké téma mikroteorií představují vhodné nástroje EV. Určité teoreticky zakotvené přehledy nástrojů přinášejí v českém kontextu publikace J. Činčery (2007, s. 59-90) a A. Máchala (2007). Z pohledu permakulturního př́stupu je podstatné, že zdaleka nejrozsáhlejší oblastí je konceptualizace zahrady jako výchovného a výukového prostředku. Tato oblast EV zná své konkrétní aplikace permakulturních principů (Gundersen, O'Day, 2008), celkově však tuto oblast chrakterizuje různorodost př́stupů odhledně toho, co a jak Ize v prípadě zahrad v EV zkoumat (Blair 2009, Skinner, Chi \& The Learning-Gardens Educational Assessment Group 2012, Mansfield, Baudains 2008). Je také zřejmé, že předmětem systematického zájmu je tato oblast již desítky let (Moore 1995) a také tato oblast je charakteristická neobyčejně velkým množstvím metodicky a prakticky zaměřených textů, které výrazně převažují nad teoretickým rámováním.

Vedle zahrady můžeme nalézt teoretické uchopení tzv. zážitkové pedagogiky, spočívající především v různých pobytech v prírodě (např. D'Amato, Krasny 2011), teorie vyu- 
žití her (Cutter-Mackenzie, Edwards 2013) či příběhů (Janoušková, Kukal 2008) především $\checkmark$ ranném dětství, časté je také využití projektové metody, která vyhovuje posunu od akademických k praktickým dovednostem. Své místo má také reflexe využití vědy a techniky (např. moderní technologie ve vyučování atd.) v EV v konkrétním např. školním provozu (např. Payne 2006b, Činčera 2014) nebo v širším kontextu sociálního učení (Dlouhá, Zahradník 2015).

Čtvrtou výraznou oblastí mikroteorií EV rozvíjenou v posledním dvacetiletí jsou koncepty tzv. místně založeného vzdělávání (place based education). Také zde je celá řada čistě empirických př́padových studií (např. Howley A., M. Howley, Camper, Perko 2011; Russ, Peters, Krasny, Stedman 2015), které však mají své širší teoretické zázemí bud' v psychologické teorii (Kudryavtsev, Stedman, Krasny 2012), nebo v dalších spíše sociologicky založených konceptech, jež propojují ekologické a komunitní aspekty (viz Smith 2013). Toto pojetí má své zastoupení i v české odborné literatuře k EV (např. Havlůjová, Foltýn, Charvátová 2012, Dlouhá 2013). Uvedené podtéma EV vykračuje z rámce propř́rodně orientované výuky k šířji pojatému prostředí. Studie (Havlůjová, Foltýn, Charvátová 2012) ukazuje, že místně zakotvená výuka má paradoxně největší potenciál právě $v$ regionech, kde došlo z různých důvodů k přetrhání vazby a tradice, přičemž namísto ochrany prírody $v$ tradičním slova smyslu se autoři zaměřují na kulturně historické dědictví, kde např. krajina může představovat jednu z jeho součástí. Místně zakotvený př́stup je třeba odlišit od konceptu EV pro určitý region (zemí, kraj, město, obec), protože takováto koncepce nemusí vůbec být místně zakotvená v onom specifickém slova smyslu kultivace smyslu pro místo (to dokládá např. dobře zpracovaná koncepce pro hl. město Prahu (Kažmierski, Svobodová 2005). Tato poslední podoblast zájmu mikroteorií, které EV zasazuje do konceptu místa zahrnujícího nejen přírodní prostředí má své přirozené pokračování v úrovni teorií, které EV rámují v širokých sociálních, politických a ekonomických souvislostech a diskutujeme je ve třetí podkapitole rámující EV celospolečensky a globálně.

\section{Mezoteorie (teorie EV středního dosahu jako teorie "o" EV)}

Zatímco mikroteorie jsou teoriemi „uvnitř" EV jakýmisi stavebními kameny EV, mezoteoriemi jakožto teoriemi středního dosahu míním teorie "O" EV. Mezoteorie představují rozdílné principy př́stupu $\mathrm{k} E \mathrm{E}$ jako celku. $V$ současnosti existuji i $v$ češtině dostupné typologie prístupů $\mathrm{k}$ EV jako celku, přičemž klíčovým autorem těchto reflexí je již vícekrát citovaný J. Činčera (srov. např. Činčera 2006; 2007, s. 16-58; 2008; 2009; 2013a), česká teoretická reflexe EV jako celku se však datuje minimálně od poloviny devadesátých let 20. století, kdy byly publikovány pilotní práce H. Horké (Horká 1993, 1996), které však nevznikaly v intelektuálním vakuu (viz např. Nosek a kol. 1979, Kočí a kol. 1986)

Za poměrně reprezentativní přehled soudobých mezoteorií, který přináší celou řadu pohledů na EV jako celek z různých hledisek (regionální, filosofická a metodologická, interdisciplinární, z pohledu různých rovin spravedlnosti jako je environmentální, ale i sociální rodová, etnická, z pohledu kulturního kontextu, z pohledu implementace veřejných politik, apod.) můžeme považovat rozsáhlou publikaci (Stevenson, Brody, Dillon, Wals 2013), která se snaží $v 51$ př́spěvcích různých autorů a autorských týmů (pocházejících z 15 zemí šesti kontinentů, většinou však $z$ anglofonního světa) přinést podstatné pohledy na EV strukturované do devíti sekcí. Určitou slovensko-českou paralelou je multioborově pojatá kolektivní publikace (Andreotti, Burjan, Činčera, Gallayová, Hipš, Huba, Kagawa, Krajhanzl, Labašová, Máchal, Medal, Piláriková, Selby 2015) Součástí konceptualizací EV jsou i pokusy o teoretické syntézy. Např. Cole (2007) se snaží o propojení kritické teorie, inkluzivní pedagogiky a místně zakotveného učení a výchovy.

Jak z přehledových publikací, tak z dalších zdrojů zahrnutých do uskutečněného přehledu vyplývá, že jedním z klíčových témat současných mezoteorií je koncept kurikula 
EV(Payne, 2006). Kurikulum je pritom spiše ohniskem, ve kterém se protínají různé názory, než že by výzkumníci $v$ oblasti EV směřovali $k$ jednotné koncepci, ačkoli i tyto hlasy bylo možné $v$ minulosti zaslechnout (Walker, 1997). Koncept kurikula je diskutován i kritizován např. v souvislostech kritické pedagogiky (Payne, 1999; Walker 1999), po roce 2000 dochází k posunu ke koncepci udržitelnosti (např. Gough \& Scott. 2001), ale vynořuje se řada dalších perspektiv (např. diskuse nad pojmem př́rody $v$ kurikulárních dokumentech (St. Maurice, 2006) Určitým shrnutím světové debaty je přehledová studie Lotz-Sisitka, Fien, Kelthoilwe (2013) v citované kolektivní publikaci (Stevenson \& Brody \& Dillon \& Wals, 2013), pro český kontext je relevantní Činčerův komentář přijatého vládního konceptu (Činčera, 2011) nebo kolektivní dílo (Leskovcová \& Matoušková Prylová \& Palacká, 2012).

\section{Makroteorie (teorie rámující EV celospolečensky a globálně)}

Teorie rámující EV celospolečensky a globálně (makroteorie) tvoří třetí typ teorií environmentální výchovy. Těmto teoriím dominuje makroperspektiva, v níž je vzdělání obecně a EV speciálně vnímáno jako součást širších společenských konfigurací. Netradiční př́stup předkládá Krasny a Roth (2010), kteří uvažují o EV nikoli jako o prípravě na (budoucí) jednání, ale jako součást samotné environmentální praxe, jako konstitutivní prvek socioekologického systému.

Většina teorií tohoto typu je charakteristická tím, že se na EV dívá z ještě širší perspektivy. Nepřehlédnutelnou a dominantní oblast těchto teorií představuje výchova k udržitelnému rozvoji rámované konceptem globalizace (Horká 2000, 2005). Téma udržitelného rozvoje $v$ EV by bylo předmětem na samostatnou srovnávací studii, je zachyceno $\checkmark$ nesčetných textech implementace soudobé vzdělávací politiky. Pokus o přehled $v$ rámci podkapitoly této mapující studie tedy bude vzhledem $\mathrm{k}$ šiŕi tématu udržitelného rozvoje nutně neúplný (určitý pokus o zachycení debaty viz (Leal Filho, 2011)).

Pro účely této studie je podstatné vědět, že z pohledu rozvoje teorie EV tento typ teorií (makroteorií) charakterizuje určitý posun od ochrany prírody k širšímu humanismu (Strife 2010), přičemž reflexe těchto změn je reflektována v různých dílčích pracích od konce 90. let 20. století (např. Bamford 1999, Smyth 2006, Dlouhá, Dlouhý 2014). Rámcem tohoto typu teorií není nic menšího než role vzdělání v soudobém světě, přičemž se tomuto problému s ohledem na pojem trvalé udržitelnosti věnuje systematická teoretická pozornost (za všechny např. monotematické číslo časopisu Educational Philosophy and Theory: Bosselmann 2001, Luke 2001, Padella 2001, Peters 2001).

\section{Filosofické a etické teorie EV}

Ekologicky orientovaná filosofie dnes tvoři samostatnou podoblast filosofického výzkumu a má své relevantní zástupce i $v$ českém a slovenském prostředí (J. Šmajs, S. Komárek, E. Kohák, V. Cílek, B. Binka, E. Višňovský ad.). Nelze nezmínit z oblasti environmentalistiky práci $\mathrm{H}$. Librové, nebo ze sféry ekopsychologie J. Krajhanzla. $V$ našem přehledu nás ale zajímají specializovanější práce, které aplikují filosofické a etické koncepce na EV prímo a je to jejich hlavním cílem, nikoli pouze jako prídavkem $k$ samostatně stojící filosofii či etice. I v této "reziduální" verzi filosofické a etické teorie EV zůstávají těmi nejobecnějšími koncepcemi EV, které budto EV zasazují do určité širší filosofické a/nebo etické koncepce, nebo využívají filosofických postupů pro výzkum v oblasti EV.

Z hlediska pedagogiky jsou důležité práce filozofa J. Šmajse rezonující následně také např. $v$ pedagogických textech $H$. Horké. Šmajs hovoří o kopernikánském obratu vědy, 
zdůrazňuje její sociální funkci, jež bude rozhodovat o přežití lidského druhu, kultury. Kopernikánský obrat představuje biofilní ${ }^{17}$ duchovní orientaci kultury, nástup biofilního paradigmatu (Šmajs 2013). Na cestě této proměny je nutná zásadní proměna vzdělávacího procesu, jeho biofilní orientace (Šmajs, 2007, 2013; Horká, 2005, 2013) .

Ačkoli existují práce, které se snaží o celkové zarámování EV ve filosofických debatách (Dlouhá, 2006a), doménou filosofických teorií EV je praktická filosofie neboli etika. I zde existují systematičtější přehledy (např. Dlouhá, 2007), avšak zdaleka nejčastějším př́stupem je využití koncepce jednoho konkrétního myslitele a její aplikace na problémy EV. Mezi komentovanými mysliteli jsou nejen ti, kteř́ jsou zároveň uznávanými „ekofilosofy", jako např. A Naess (Binka, 2007), A. Leopold a J. Muir (Goralnik \& Nelson 2011) nebo představitelé biocentrické etiky A. Schweitzer A P. W. Taylor (Binka \& Labohý 2010), ale také autoři, kteří se o environmentální problémy nezajímali bud' vůbec, nebo spíše jen okrajově: S. H. Schwartz (Binka \& Činčera \& Černý, 2015), J. Dewey (Dennis \& Knapp, 1997), E. Levinas (Hardy, 2002), Heidegger a Kiekegaard (Olšovský, 2011). Z českých filosofů pak klasikové filosofie výchovy Komenský (Dlouhá, 2007b; Sedláček, 2007; Sedláček, 2011) a Patočka (Dlouhá, 2006b).

Druhou oblastí je aplikace filosofických postupů v rámci EV nebo na některé dílčí problémy EV. Jedním z takových dílčích, ale filosoficky nosných problémů je otázka využití moderních technologií $\vee$ EVV (Payne, 2006) nebo problém komplexity $\vee$ EV plynoucí z průřezovosti tématu González-Gaudiano (2001). A. Stabels věnuje pozornost otázkám jazyka a narací EV (Stables 1999, 2001, 2006). Určitou podoblastí využití filosofie je obhajoba užitečnosti obecných filosofických postupů (spekulace) pro EV jako celek, především pro ukázněnou práci s pojmy (Dlouhá, 2009b; Vladyková, 2015), ale také pro rozvíjení teoretické senzitivity pro předmětnou problematiku, at již je jí př́roda nebo proces učení se o ní a formování př́stupu k ní (Payne, 2013; Olšovský, 2013).

\section{Shrnutí}

S ohledem na základní rozdělení teorií výchovy na empirické a filosofické (Prokop, 2009 in Průcha, 2009b) jsem si teoretické př́stupy k EV rozčlenila podle míry obecnosti (abstrakce) a širre záběru do čtyř podoblastí, které jsem si pracovně nazvala: mikroteorie, mezoteorie (teorie středního dosahu jakožto teorie "O" EV), makroteorie (rámující EV celospolečensky a globálně), filosofické a etické teorie EV.

Uskutečněný přehled ukázal, že zdaleka nejrozsáhlejší oblastí jsou koncepty, které jsem nazvala mikroteorie. $V$ jejich rámci dominují čtyři tematické oblasti: (mikro) teorie postojů zkoumající vztah mezi vědomím a jednáním; teorie různých nástrojů $\mathrm{EV}$, přičemž rozsáhlou podoblast tvoří téma zahradničení; teorie tzv. místně zakotveného učení, která ze zaměření EV na přírodní prostředí rozšiřuje svoji perspektivu směrem $\mathrm{k}$ sociálnímu prostředí a kulturnímu dědictví; zvláštní kapitolu tvoří evaluace EV.

Zatímco mikroteorie jsou teoriemi "V EV", mezoteorie jsem si vymezila rámcově jako specializované teorie "o EV". Těmto teoriím dominuje koncepce kurikula, která nepředstavuje ani tak nějakou převládající teorii, jako spiše důležité ohnisko zájmu, ve kterém se protínají různé pohledy o tom, jak by měla být EV jako celek koncipována.

\footnotetext{
${ }^{17}$ Tzn. „životu přející".
} 
Teorie rámující EV celospolečensky a globálně (makroteorie) jsou třetí podoblastí. Jejich cílem není nic menšího, než určit úlohu vzdělání v současném světě. Dominantním pojmem této oblasti je "udržitelný rozvoj" a zasazení EV a vzdělání jako celku do konceptu globalizace. Tato oblast teorií je neobyčejně rozsáhlá. Mohutnost této oblasti ukazuje na důležitý posun EV od ochrany př́rody $\mathrm{k}$ širší humanistické perspektivě. ${ }^{18}$ Je však třeba mít na paměti, že nejde o nějakou teorii, ale skutečně široce vymezenou ideologickou perspektivu. $V$ uvedené podoblasti se Ize setkat i s teoriemi, které se bez odvolávání na udržitelný rozvoj obejdou a jednoduše zkoumají EV jako součást socio-ekologického systému.

$\checkmark$ podoblasti filosofických teorií EV $v$ plném slova smyslu Ize najít dva základní př́stupy. Tím prvním je používání výsledků filosofické etiky na poli EV plynoucí z toho, že EV je silně normativně zakotvená disciplína. Druhým typem filosofické reflexe je využití filosofických spekulativních postupů a pojmů při řešení dílčích konceptuálních otázek EV, at' už se jedná např. o využití postupů fenomenologie na poli EV nebo o analýzu jazyka EV.

\section{Závěr a diskuse}

Ačkoli použitá metoda výběru má svá omezení, spočívající zejména v selektivním výběru zdrojů, jejich převážně informativním zpracování a poměrně úzkému zaměření přehledu, přesto je možné na jeho základě formulovat několik závěrů. Domnívám se, že i přes svou neúplnost poskytuje přehled adekvátní představu o klíčových tématech a do určité míry i autorech $v$ podoblasti teoretického pedagogického výzkumu EV, což je nezbytný předpoklad jakékoli další aplikace konceptu permakultury (a vlastně jakéhokoli konceptu) $v$ této rovině.

Uskutečnění přehledu napomůže identifikovat klíčové teoretiky. S ohledem na český kontext můžeme říci, že teoretické uchopení EV se zde systematicky rozvíjelo v 90 . letech 20. století a navazovalo na snahy předchozí dekády. Klíčovými autory jsou H. Horká a A. Máchal. Práce A. Máchala jsou výrazně prakticky orientované, do oblasti teorie přesahují především $v$ př́ležitostných reflexích poučeného praktika, teorie však není jeho cílem. Texty $\mathrm{H}$. Horké z poloviny 90 . let představují pilotní pokusy o systematické zarámování environmentální výchovy zprvu pojaté úžeji jako ekologické výchovy, pozdě šířeji jako výchovy globální. Zatímco Máchalovy reflexe bychom mohli přiřadit blíže k pólu empirických teorií EV, práce $H$. Horké přistupují k EV z širší perspektivy, přinášejí abstraktnější reflexi a mají relativně blíž k filosofickým teoriím EV.

Na práce těchto autorů navazují texty nové generace, s těžištěm publikační aktivity po roce 2000. Z uvedeného přehledu vystupují do popředí texty J. Činčery a J. Dlouhé. Pro práce obou autorů je charakteristické, že neuvádí nové pole pedagogického výzkumu (což bylo rolí textů 90 . let), ale piší specializované studie $v$ jejich rámci, at' už přehledové nebo dílčí. Ačkoli jsou oba aktivní de facto ve všech čtyřech uvedených stupních teoretické reflexe, analýzy Komenského, Patočky, environmentální etiky nebo pojmová analýza J. Dlouhé ukazuji její relativně větší zastoupení $v$ oblasti filosofické teorie, zatímco četné práce Činčery $v$ oblasti evaluace EV a systematizace paradigmatických př́stupů v EV jej vztahují relativně více $\mathrm{k}$ empiricky založené teorii.

\footnotetext{
${ }^{18}$ Dřive znamenala environmentální výchova v podstatě totéž co ekologická výchova. Také byl pro ni často tento pojem používán. Byla chápána spíše čistě přírodovědně, mající velkou spojitost s ochranou přírody. $V$ dnešní době se dává přednost termínu environmentální výchova. $V$ tomto názvu lépe rezonuje přijímaný fakt, že životní prostředí má také kulturní a sociální souvislosti a aspekty.
} 
Vzhledem k šíri výzkumného pole, bylo by zkreslující z uskutečněného přehledu vyvozovat podobné závěry, kterých jsem se odvážila pro český kontext. Žádná výrazná postava jednoznačně nevyčnívá, každý kontinent jich má celou řadu, a také kvalitativní nesouměřitelnost a různorodost témat $E V$ znemožňuje dát jednoznačné stanovisko. To je nepochybně dáno omezeností "metody" a prozatímní detailní neobeznámeností autorky se světovou debatou.

S ohledem na koncept permakultury je možné formulovat také několik závěrů. Tím prvním je, že permakultura je koncept na periferii teoretických diskusí EV. Nenalezneme jej v hlavních přehledových publikacích výzkumu v oblasti EV (např. Stevenson \& Brody \& Dillon \& Wals, 2013), a pouze marginálně v klíčových periodikách. Na stranu druhou termín permakultura se vyskytuje $v$ kontextu environmentální výchovy poměrně často $\checkmark$ prakticky zaměřených pracích na různých úrovních: od kvalifikačních prací studentů, až po výstupy specializovaného výzkumu odborníků. Nicméně jde většinou bud' o př́ležitostné a ad hoc využití dílčích poznatků permakulturního zemědělství ve školních zahradách, nebo abstraktní pojednání o hodnotových závazcích pedagogiky 21. století jako celku, prípadně studie o permakulturním hnutí. Existuje řada realizací školních permakulturních projektů a to především v těch částech světa, kde jde "do tuhého" a kde se péče o krajinu a udržitelné zemědělství stalo prioritou $z$ hlediska prostého přežití a získávání potravin. $V$ textech vztažených k permakulturní praxi jsou často obsaženy pasáže o potřebě nového vzdělání, ale jedná se spíše o obecné programové projevy, nebo spiše jen prohlášení, nikoli promyšlenou pedagogickou koncepci. Této touze představitelů permakultury nápadně konotuje volání po biofilní orientaci vzdělávání ozývající se $v$ českém kontextu zejména $v$ textech $\mathrm{H}$. Horké a J. Šmajse ${ }^{19}$. Společný mají také důraz na vnímání systémovosti, porozumění v souvislostech a upozorňování na vzájemnou provázanost vztahů v rámci celku

Zatímco má permakultura své místo v pedagogické praxi, pro pedagogickou teorii představuje výzvu. Následující řádky jsou tedy spíše zamyšlením nad možným směřováním výzkumu, který by mohl stavět na zjištěních a systematice uskutečněného přehledu vycházejícího z dělení na empirické a filosofické teorie EV.

Permakultura je prozatím nástrojem praxe EV, proto je její potenciál největší na empirickém pólu teorií EV. V oblasti mikroteorie by mohla být navázána na oblast konceptualizace nástrojů EV, především výuky prostřednictvím permakulturní zahrady, a jednak $\checkmark$ konceptech místně zakotvené výchovy a výuky, přičemž asi nic nebrání tomu pokusit se obě oblasti propojit. Je spíše otázkou pro empirický výzkum, zda Ize s využitím permakulturních principů dosáhnout jiných postupů a jiných výsledků z pohledu výchovy, než je využití "klasické" školní zahrady. Permakultura reprezentuje systémový přistup ke skutečnosti.

Z pohledu sociálního rámování nelze přehlédnout, že permakultura má své místo $v$ komunitním př́stupu, tj. je realizována jako součást soběstačných zemědělských komunit, čímž je naplňován základní princip místního zakotvení, charakteristický pro podstatnou část mikroteorií EV. Z této perspektivy by mohla aplikace permakultury na výchovu (včetně vzděláván) spočívat $v$ dalším rozvíjení tohoto principu odspoda nahoru. Tj. nepřizpůsobovat místo a děti potřebám výuky, ale výuku odvíjet od poznání místa a poznání dětí. Teoreticky by mohlo být možné i trrídu zkoušet koncipovat jako dlouhodobě udržitelný sys-

\footnotetext{
${ }^{19}$ Např. Šmajs, J. (2007). Potřebujeme filosofii přežití? Úvahy o filosofii, kultuře, poznání, vzděláním. Brno, nebo Horká, H. (2005). Ekologická dimenze výchovy a vzdělávání ve škole 21. století. Brno: MSD.
} 
tém, založený asi na dlouhodobosti práce a záměrnému vytváření funkčních vazeb uvnitř trrídy. $Z$ toho vyplývá zaměření teoretického výzkumu na koncepce podobného typu. Jedním z dominantních směrů komunitně zaměřené výuky je tzv. waldorfská škola, kde je důraz na komunitu. Permakultura může přidat propojení na systémový přístup k prírodě. $Z$ této perspektivy permakultura může aplikace permakulturních principů představovat pokus o jakýsi lokálně ukotvený „zelený pedagogický funkcionalismus".

Přestože permakulturu Ize zatím zřetelně identifikovat spíše $v$ oblasti mikroteorií, nelze přehlédnout, na úrovni makroteorií, její podobnost s globální výchovou. Lehce odlišnými pojmy klade permakultura důraz na stejné prvky jako globální výchova (viz obrázek $1,2,3 \vee$ př́loze). Zejména na to, co globální výchova označuje jako planetární vědomí (propojenost na úrovni prostoru i času, respektování principu "jedné Země", kdy zájmy jednotlivců i jednotlivých států je nutné vnímat s vědomím potřeb celé planety), reflektování globálních rizik a systémový, holistický prístup a světu a skutečnosti (důraz na vztahy a provázanost mezi prvky daného systému).

Co se týká druhého pólu filosoficky zakotvených teorií, permakultura není abstraktní filosofickou teorií $v$ tom smyslu, že netvoři dostatečně propracovaný systém pojmů a kategorií, mohla by být využitelná jako odrazový můstek takové teorie. Příčina je v tom, že obrazně řečeno vyrůstá od země k nebi, vyrůstá z bezprostřední praxe. Nemá propracované nejobecnější pojmy, ale má propracovanou koncepci světa s vazbou na zdravý rozum, praxi, život. Proto by mohla mít potenciál jako teorie středního dosahu (mezoteorie). $\mathrm{Na}$ vyšších patrech teoretické abstrakce může být př́spěvek permakultury spiše $v$ rovině kompatibility s určitou obecnější filosofií a etikou. Permakultura může filosofii inspirovat, doplnit, ale ne nahradit. Vzhledem $\mathrm{k}$ tomu, že mezi principy permakulturního př́stupu patř́ určitá forma holistického funkcionalismu, zřetelný hodnotový rozměr a důraz na lokální zakotvení každého systému, nosným tématem se jeví navázat na komeniologickou a patočkovskou linii teoretického výzkumu. Komenský jako myslitel stojící v opozici kartezianismu, snažící se vědění, hodnoty a praxi propojit do jednoho provázaného celku, se zdá být vhodným kandidátem. Patočka permakultuním principům konvenuje jak důrazem na zakotvení ve světě a fenomenologickou analýzou domova. Bylo by také velmi permakulturní vytěžit "lokální" filosofické dědictví.

\section{Poděkování}

Závěrem by autorka textu ráda poděkovala svojí školitelce paní doc. PaedDr. Haně Horké, CSc. za připomínky k pracovní verzi textu, za impuls $\mathrm{k}$ jeho publikaci a za odbornou podporu $v$ doktorském studiu.

\section{Seznam literatury}

- Andreoti, V., Burjan, V., Činčera, J., Gallayová, Z., Hipš, J., Huba, M., Kagawa, F., Krajhanzl, J., Labašová, Z., Máchal, A., Medal, R., Piláriková, M., Selby, D. (2015). Environmentálna výchova v súvislostiach. 1. vydanie. Zvolen: Technická univerzita vo Zvolene.

- Bertrand, Y. (1998). Soudobé teorie vzdělávání. Praha: Portál.

- Binka, B. (2007). Rozporuplný Arne Naess - několik poznámek k zakladateli hlubinné ekologie I. Envigogika, 2(2), 1-11. Dostupný z

http://dx.doi.org/10.14712/18023061.16 
- Binka, B., Labohý, J. (2010). Aplikace testu naturalistického chybného závěru G. E. Moora na koncept biocentrické etiky u A. Schweitzera a P. W. Taylora. Envigogika, 5(2), 1-21. Dostupné z http://dx.doi.org/10.14712/18023061.52

- Blair, D. (2009) The Child in the Garden: An Evaluative Review of the Benefits of School Gardening, The Journal of Environmental Education, 40(2), 15-38, Dostupné z http://dx.doi.org/10.3200/JOEE.40.2.15-38.

- Binka B., Činčera J., Černý M. (2015). Hodnoty v opravdovém světě. Envigogika, 10(3), 1-17. Dostupné z http://dx.doi.org/10.14712/18023061.505

- Broukalová, L. (2011). Cíle a indikátory pro environmentální vzdělávání, výchovu a osvětu $v$ České republice. Praha: Ministerstvo životního prostředí České republiky. Dostupné z: http://www.mzp.cz/cz/cile_indikatory_evvo_dokument.

- Bultu, Z., Yilmaz, S. (2008). „Permaculture Playgrounds as a New Design Approach for Sustainable Society" International Journal of Natural and Engineering Sciences, 2 (2): $35-40$.

- Cutter-Mackenzie, A., \& Edwards, S. (2013). Toward a Model for Early Childhood Environmental Education: Foregrounding, Developing, and Connecting Knowledge Through Play-Based Learning. The Journal of Environmental Education, 44(3), 195213. Dostupné z http://dx.doi.org/10.1080/00958964.2012.751892

- Činčera, J. (2006). Trendy v environmentální výchově - interpretivistický a kritický proud. Envigogika, 1(1), 1-8. Dostupné z http://dx.doi.org/10.14712/18023061.2

- Činčera, J. (2007). Environmentální výchova: od cílů k prostředkưm. Brno: Paido.

- Činčera, J. (2008a). Evaluace program Ekoškola. Envigogika, 3(2), 1-32. Dostupné z http://dx.doi.org/10.14712/18023061.30

- Činčera, J. (2008b). Evaluační strategie středisek ekologické výchovy. Envigogika, 3(2), 1-18. Dostupné z http://dx.doi.org/10.14712/18023061.29

- Činčera, J. (2008c). Výchova k udržitelnému rozvoji: mýtus nebo nová vIna? Envigogika, 3(1), 1-7. Dostupné z http://dx.doi.org/10.14712/18023061.25

- Činčera, J. (2009). Výstupy či procesy: pragmatický (kvazi)spor environmentální výchovy. Envigogika, 4(2), 1-12. Dostupné $\mathrm{z}$ http://dx.doi.org/10.14712/18023061.38

- Činčera, J. (2011). Doporučené očekávané výstupy pro environmentální výchovu. Envigogika, 6(2), 1-17. Dostupné z http://dx.doi.org/10.14712/18023061.59

- Činčera, J. (2013a). Environmentální výchova: efektivní strategie. Praha: Agentura Koniklec a Brontosauř́ ekocentrum Zelený klub, Brno: Masarykova univerzita.

- Činčera, J. (2013b). Metodika pro hodnocení environmentální výchovy pro předškolní a mladší školní věk. Envigogika, 8(5), 1-52. Dostupné z http://dx.doi.org/10.14712/18023061.413

- Činčera, J. (2013c). Paradigmatická proměna domácího pojetí environmentální výchovy. Pedagogika: časopis pro vědy o vzdělávání a výchově, 63(2), 182-197. 
- Činčera, J., Gilar, P., Sokolovičová, J. (2010). Specializační studium pro koordinátory environmentální výchovy, vzdělávání a osvěty: interpretace a efektivita z pohledu absolventů. Envigogika, 5(1), 1-20. Dostupné z http://dx.doi.org/10.14712/18023061.47

- Činčera, J., Kulich, J., Gollová, D. (2009). Efektivita, evaluace a podpora programů environmentální výchovy. Envigogika, 4(2), 1-31. Dostupné z http://dx.doi.org/10.14712/18023061.39

- Činčera, J. (2014). Význam nezávislých expertních center pro šíření badatelsky orientované výuky v České republice (The Importance of Independent Expert Centres for Dissemination of Inquiry-based Learning Approach in the Czech Republic). Scientia in educatione, 2014, 5(1), 74-81.

- Darner, R. (2012). An empirical test of self-determination theory as a guide to fostering environmental motivation. Environmental Education Research, 18(4), 463-472. Dostupné z http://dx.doi.org/10.1080/13504622.2011.638739

- Dennis, L. J., \& Knapp, D. (1997). Viewpoint: John Dewey as Environmental Educator. The Journal of Environmental Education, 28(2), 5-9. Dostupné z http://dx.doi.org/10.1080/00958964.1997.9942817

- Dillion, J. (2003). On Learners and Learning in Environmental Education: Missing theories, ignored communities. Environmental Education Research, 9(2), 215-226. Dostupné z http://www.tandfonline.com/doi/abs/10.1080/13504620303480

- Dlouhá, J. (2006). Environmentální vzdělání - pokus o systematické pojmenování problému. Envigogika, 1(1), 1-10. Dostupné z http://dx.doi.org/10.14712/18023061.7

- Dlouhá, J. (2006). Zkušenost př́rody - jaká je a co ve výchově znamená. Envigogika, 1(1), 1-6. Dostupné z http://dx.doi.org/10.14712/18023061.3

- Dlouhá, J. (2007). Ekologická etika - na pomezí etikety a revoluční ideologie. Envigogika, 2(1), 1-18. Dostupné z http://dx.doi.org/10.14712/18023061.13

- Dlouhá, J. (2007). Pansofie v díle Jana Ámose Komenského. Envigogika, 2(2), 116. Dostupné $z$ http://dx.doi.org/10.14712/18023061.18

- Dlouhá, J. (2009). Obecné vzdělávací kvality a pojem kompetence. Envigogika, 4(1), 1-19. Dostupné z http://dx.doi.org/10.14712/18023061.35

- Dlouhá, J. (2009). Trojští koně filosofických textů. Envigogika, 4(1). Dostupné z http://dx.doi.org/10.14712/18023061.295 Vol 4, No 1 (2009)

- Dlouhá, J. (2013). Místně zakotvené učení: výuka pomocí regionálních materiálů a př́padových studií: př́ručka k projektu Věda do škol. Praha: Univerzita Karlova v Praze, Pedagogická fakulta.

- Dlouhá, J., Dlouhý, J. (2014). Higher education for sustainability - a change of education genre? Envigogika, 9(1), 1-31. Dostupné z http://dx.doi.org/10.14712/18023061.440 
- Dlouhá, J., Zahradník, M. (2015). Potenciál pro sociální učení v regionálním udržitelném rozvoji: analýza interakcí aktérů s dưrazem na roli vědců. Envigogika, 10(1), 1-23. Dostupné z http://dx.doi.org/10.14712/18023061.476

- Dunlap, R., E. (2008). The New Environmental Paradigm Scale: From

- Dunlap, R.E., \& Van Liere, K.D. (2008). The "New EnvironmentalParadigm". The Journal of Environmental Education, 40(1), 19-28. Dostupné z http://dx.doi.org/10.3200/JOEE.40.1.19-28

- Froněk, J. (2012). Permakultura v mém pracovním životě (2. díl). Klíčová dírka č. 3, str. 12-13.

- Gahl Cole, A. (2007). Expanding the Field: Revisiting Environmental Education Principles Through Multidisciplinary Frameworks. The Journal of Environmental Education, 38(2), 35-45. Dostupné z http://dx.doi.org/10.3200/JOEE.38.1.35-46

- Galen D'Amato, L., \& Krasny, M. E. (2011). Outdoor Adventure Education: Applying Transformative Learning Theory to Understanding Instrumental Learningand Personal Growth in Environmental Education. The Journal of Environmental Education, 42(4), 237-254. Dostupné z http://dx.doi.org/10.1080/00958964.2011.581313

- González-Gaudiano, E. (2001). Complexity in Environmental Education1. Educational Philosophy and Theory, 33(2), 153-166. Dostupné z http://dx.doi.org/10.1111/j.1469-5812.2001.tb00260.x

- Goralnik, L., \& Nelson, M. P. (2011). Framing a Philosophy of Environmental Action: Aldo Leopold, John Muir, and the Importance of Community. The Journal of Environmental Education, 42(3), 181-192, Dostupné z http://dx.doi.org/10.1080/00958964.2010.526152

- Gough, S., Scott, W. (2001). Curriculum Development and Sustainable Development: practices, institutions and literacies. Educational Philosophy and Theory, 33(2), 137-152. Dostupné z http://dx.doi.org/10.1111/j.14695812.2001.tb00259.x

- Green, C. G. (2015). Toward Young Children as Active Researchers: A Critical Review of the Methodologies and Methods in Early Childhood Environmental Education. The Journal of Environmental Education, 46(4), 207-229. Dostupné $z$ http://dx.doi.org/10.1080/00958964.2015.1050345

- Grmelová, L. (2014). Vzdělávání pro zdraví prostřednictvím komunitní zahrady s permakulturními prvky (Bakalářská práce). Brno: MU.

- Gundersen, D. T., O'Day, T. (2008). Permaculture, a natural systems design approach for teaching sustainability in higher education: Pacific University's B-Street permaculture project. In: Allen-Gil, S., Stelljes, L., Borysova, O. (eds.) Addressing Global Environmental Security Through Innovative Educational Curricula (s. 165 178). Dordrecht (The Netherlands): Springer.

- Gundersen, D. T., O'Day, T. (2008). Permaculture, a natural systems design approach for teaching sustainability in higher education: Pacific University's B-Street permaculture project. In Allen-Gil, S., Stelljes, L., Borysova, O. (eds.), Addressing 
Global Environmental Security Through Innovative Educational Curricula (165 178). Dordrecht (The Netherlands): Springer.

- Hardy, J. (2002). Levinas and Environmental Education. Educational Philosophy and Theory, 34(4), 459-476. Dostupné $z$ http://dx.doi.org/10.1111/j.14695812.2002.tb00519.x

- Havlůjová, H., Foltýn, D., Charvátová, K. (2012). Výchova ke vztahu ke kulturně historickému dědictví a vzdělávání pro udržitelný rozvoj v ČR. Envigogidka, 7(3), 1-18. Dostupné z http://dx.doi.org/10.14712/18023061.78

- Holmes, J. A. (2014). Permaculture and Contemporary Utopian Romanticism. Citizenship and Globalisation Research Papers, 5(5), 1-19.

- Holmgren, D. (2006). Permakultura: principy a cesty nad rámec trvalé udržitelnosti. Svojanov: PermaLot.

- Horáčková, M. (2015). Proenvironmentální postoje učitelů středních odborných škol jako předpoklad biofilní orientace vzdělávání. Dostupné z http://www.ped.muni.cz/weduresearch/publikace/pvtp40.pdf

- Horká H. 2000. Výchova pro 21. století. Paido. Brno.

- Horká, H. (1993). Globální pojetí světa a výchovy. (Vztah ekologické výchovy a výchovy k hodnotám). Pedagogická orientace, (8/9), s. 24-28.

- Horká, H. (1996). Teorie a metodika ekologické výchovy. Brno: Paido.

- Horká, H. (1997). Učitel a globální výchova. Pedagogika, 47(3), 238-246.

- Horká, H. (2000). Výchova pro 21. století: koncepce globální výchovy v podmínkách české školy. 1. vyd. Brno: Paido.

- Horká, H. (2005). Ekologická dimenze výchovy a vzdělávání ve škole 21. století. Brno: MSD.

- Horká, H. (2013). Proměna obsahu předškolního vzdělávání v intencích biofilní orientace. Pedagogika Przedszkolna i Wczesnoszkolna. s. 79-86. Dostupné z www.ippis.up.krakow.pl.

- Howley, A., Howley, M., Camper, Ch., Perko, P. (2011). Place-Based Education at Island Community School, The Journal of Environmental Education, 42(4), 216236. Dostupné z http://dx.doi.org/10.1080/00958964.2011.55668210.1080/00958964.2011.556 682

- Hutchinson, F. P. (1996). Educating for the 21st Century: Beyond Racist, Sexist, and Ecologically Violent Futures. Peabody Journal of Education, 71(3), 42-62.

- Chao, Y., L. (2012). Predicting people's environmental behaviour: theory of planned behaviour and model of responsible environmental behaviour. Environmental Education Research, 18(4), 437-461. Dostupné z http://dx.doi.org/10.1080/13504622.2011.634970 
- Chawla, L. (1998). Significant Life Experiences Revisited: A Review of Research on Sources of Environmental Sensitivity. The Journal of Environmental Education, 29(3), 11-21. Dostupné z http://dx.doi.org/10.1080/00958969809599114

- Janík, T., Slavík, j., Najvar, P., Píšová, M. (2012). Mezi praxí a teorií v učitelském vzdělávání: na okraj českého překladu knihy F. A. J. Korthagena et al. Pedagogická orientace, roč. 22 (3), 367-386.

- Janoušková, S., Kukal P. (2008). Environmentální výchova v př́bězích. Praha: Fortuna.

- Janoušková, S., Hák, T., Maršák, J., Pachmanová, L. (2010). Charakter indikátorů udržitelného rozvoje a indikátorů vzdělávání pro udržitelný rozvoj na mezinárodní úrovni. Envigogika, 5(3), 1-18. Dostupné z http://dx.doi.org/10.14712/18023061.57

- Kažmierski, T., Svobodová, J. (2005). Praha a ekologická výchova: ekologie, výchova, vzdělávání, osvěta: koncepce environmentálního vzdělávání, výchovy a osvěty na území hlavního města Prahy pro roky 2005-2015. Praha: Hlavní město Praha.

- Bosselmann, K. (2001). University and Sustainability: compatible agendas? Educational Philosophy and Theory, 33(2), 167-186. Dostupné z http://dx.doi.org/10.1111/j.1469-5812.2001.tb00261.x

- Kočí, J. (1986). Mimoškolní výchova k péči o životní prostředí. 2., přeprac. a dopl. vyd. Praha: SNTL.

- Korthagen, F. (2012). Jak spojit praxi s teorií: Didaktika realistického vzdělávání učitelů. Brno: Paido.

- Krasny, M. E., \& Roth, W-M. (2010). Environmental education for social-ecological system resilience: a perspective from activity theory. Environmental Education Research, 16(5-6), 545-558. Dostupné z http://dx.doi.org/10.1080/13504622.2010.505431

- Kudryavtse, A.., Stedman, R. C., Krasny, M. E. (2012). Sense of place in environmental education. Environmental Education Research, 18(2), 229-250. Dostupné z http://dx.doi.org/10.1080/13504622.2011.609615.

- Kwieciński, Z., Śliwerski, B. (2004). Pedagogika. Warszawa: PWN.

- Leal Filho, W. (ed.). (2011). World Trends in Education for Sustainable Development. Frankfurt am Main, Berlin, Bern, Bruxelles, New York, Oxford, Wien: Peter Lang.

- Leblová, E. (2012). Environmentální výchova v mateřské škole. Praha: Portál.

- Leppänen, J. M., Haahla, A. E., Lensu, A. M., Kuitunen, M. T. (2012). Parent-Child Similarity in Environmental Attitudes: A Pairwise Comparison, The Journal of Environmental Education, 43(3), 162-176. Dostupné z http://dx.doi.org/10.1080/00958964.2011.634449 
- Leskovcová, M., Matoušková Prylová, L., Palacká A. (2012). Environmentální výchova $v$ České republice a v EU, systém environmentálního vzdělávání, výchovy a osvěty. 1. vyd. České Budějovice: Vysoká škola evropských a regionálních studií.

- Lewis, E., Mansfield, C., Baudains, C. (2008). Getting down and dirty: Values in education for sustainability. Issues in Educational Research, 18 (2), 138-155.

- Lewis, E., Mansfield, C., Baudains, C. (2008). Getting down and dirty: Values in education for sustainability. Issues in Educational Research, 18(2), 138-155.

- Lewis, E., Mansfield, C., Baudains, C. (2008). Getting down and dirty: Values in education for sustainability. Issues in Educational Research, 18(2), 138-155.

- Lieflander, A. K. (2014). The Effects of Children's Age and Sex on Acquiring ProEnvironmental Attitudes Through Environmental Education. Journal of Environmental Education. 45(2), 105-117. Dostupné z http://dx.doi.org/10.1080/00958964.2013.875511.

- Lotz-Sisirka H., Fien J., Kelthoilwe M. (2013). Traditions and New Niches: An Overview of Environmental Education Curriculum and Learning Research. In: Stevenson, R., B., Brody, M., Dillon, J., Walls, E.J. (Ed.), International handbook of research on environmental education (194-205). New York: American Educational Research Association.

- Luke, T. W., (2001). Education, Environment and Sustainability: what are the issues, where to intervene, what must be done? Educational Philosophy and Theory, 33(2), 187-202. Dostupné z http://dx.doi.org/10.1111/j.1469-

5812.2001.tb00262.x

- Máchal, A. (2007). Průvodce praktickou ekologickou výchovou. 2. vyd. Brno: Rezekvítek ve spolupráci s Lipkou - školským zařízením pro environmentální vzdělávání.

- Máchal, A. (2013). O některých omylech a chybách v environmentální výchově. Komenský: časopis pro učitele základní školy, 138(1), 48-53.

- Máchal, A., (2012). Mýty a omyly o environmentální výchově a v environmentální výchově. 1. vyd. Brno: Lipka - školské zařizení pro environmentální vzdělávání.

- Maňák, J., Švec V. (2003). Výukové metody. Brno. Paido, 91-104.

- Mareš, J. (2013). Přehledové studie: jejich typologie, funkce a způsob vytváření. Pedagogická orientace, roč. 23, č. 4, s. 427-454.

- Marginality to Worldwide Use. The Journal of Environmental Education, 40(1), 318. Dostupné z http://dx.doi.org/10.3200/JOEE.40.1.3-18.

- Merton, R. K. (2000). Studie ze sociologické teorie. Praha: Sociologické nakladatelství.

- Mollison B. (2012). Úvod do Permakultury. Brdárka (Slovensko): Alter Nativa.

- Moore, R. C. (1995). Children Gardening: First Steps Towards a Sustainable Future. Children's Environments, 12(2), 222-232. 
- Moore, R. C. (1995). Children Gardening: First Steps Towards a Sustainable Future. Children's Environments, 12(2), 222.

- Nosek, M. (1997). Výchova k péči o životní prostředí. Vyd. 1. Brno: Univerzita J.E. Purkyně v Brně.

- Nováček, P. (2013). Od Noemovy archy k Titaniku a zase zpátky. Brno: Lipka.

- Olšovský, J. (2011). Heideggerovo a Kierkegaardovo pojetí svobody a ospovědnosti. Envigogika, 6(2), 1-12. Dostupné z http://dx.doi.org/10.14712/18023061.61

- Olšovský, J. (2013). Myšlení a netechnický přistup k věcem, jejich chránění a ohleduplné (básnické) zacházení s nimi. Envigogika, 8(3), 1-12. Dostupné z http://dx.doi.org/10.14712/18023061.389

- Payne P. (1999). Postmodern Challenges and Modern Horizons: education 'for being for the environment', Environmental Education Research, 5(1), 5-34. Dostupné z http://dx.doi.org/10.1080/1350462990050101

- Payne, P. (2002). Post-metatheorizing Environmental Behaviours in Environmental Education. Environmental Education Research, 8(3), 307-314.

- Payne, P. (2006a). Environmental Education and Curriculum Theory. The Journal of Environmental Education, 37(2), 25-35. Dostupné z http://dx.doi.org/10.3200/JOEE.37.2.25-35

- Payne, P. (2006b). The technics of environmental education. Environmental Education Research, 12(3-4), 487-502. Dostupné z http://dx.doi.org/10.1080/13504620600943103.

- Payne, P. (2013). (Un)timely Ecophenomenological Framings of Environmental Education Research. In Stevenson, R., B., Brody, M., Dillon, J., Walls, E.J. (Ed.), International handbook of research on environmental education (424-437). New York: American Educational Research Association.

- Pe'er S., Goldman, G., Yavetz B. (2007). Environmental Literacy in Teacher Training: Attitudes, Knowledge, and Environmental Behavior of Beginning Students. The Journal of Environmental Education, 39(1), 45-59. Dostupné z http://dx.doi.org/10.3200/JOEE.39.1.45-59

- Peters, M. (2001). Environmental Education, Neo-liberalism and Globalisation: the 'New Zealand experiment'. Educational Philosophy and Theory, 33(2), 203-216. Dostupné z http://dx.doi.org/10.1111/j.1469-5812.2001.tb00263.x

- Průcha, J. (2009a). Moderní pedagogika. Praha: Portál.

- Průcha, J. (ed.). (2009b). Pedagogická encyklopedie. Praha: Portál.

- Russ A., Scott J. Peters, Marianne E. Krasny, Stedman, R. C. (2015). Development of Ecological Place Meaning in New York City. The Journal of Environmental Education, 46(2), 73-93. Dostupné z http://dx.doi.org/10.1080/00958964.2014.999743.

- Sedláček, Z. (2007). Komeniánská filosofie pro ekology. Envigogika, 2(3). Dostupné $\mathrm{z}$ http://dx.doi.org/10.14712/18023061.125 
- Sedláček, Z. (2011). Komenský se vrací. Envigogika, 6(1). Dostupné $\mathrm{z}$ http://dx.doi.org/10.14712/18023061.262

- Shuman, E., K., Ham, S. H. (1997). Toward a Theory of Commitment to Environmental Education Teaching. The Journal of Environmental Education, 28(2), 25-32. Dostupné $\mathrm{z}$ http://dx.doi.org/10.1080/00958964.1997.9942820

- Schelly, Ch., Cross, J. E., Franzen, W., Hall, P., \& Reeve, S. (2012). How to Go Green: Creating a Conservation Culture in a Public High School Through Education, Modeling, and Communication. The Journal of Environmental Education, 43(3), 143-161. Dostupné z http://dx.doi.org/10.1080/00958964.2011.631611

- Schovajsová, J. (2010). Současný stav environmentální výchovy na základních školách - vybrané aspekty environmentální gramotnosti dětí mladšího školního věku (Disertační práce). Olomouc: Univerzita Palackého.

- Skinner, E. A., Chi, U., \& The Learning-Gardens Educational Assessment Group. (2012). Intrinsic Motivation and Engagement as "Active Ingredients" in GardenBased Education: Examining Models and Measures Derived From SelfDetermination Theory. The Journal of Environmental Education, 43(1), 16-36. Dostupné z http://dx.doi.org/10.1080/00958964.2011.596856

- Smith, G. A. (2013). Place based education. In Stevenson, R., B., Brody, M., Dillon, J., Walls, E.J. (Ed.), International handbook

- Spousta, V. (2003). Jak psát recenze. Pedagogická orientace 1.

- Squella Padilla, M. P. (2001). Environmental Education to Environmental Sustainability. Educational Philosophy and Theory, 33(2), 217-230. Dostupné z http://dx.doi.org/10.1111/j.1469-5812.2001.tb00264.x

- Stables, A. (2001). Who Drew the Sky? Conflicting assumptions in environmental education. Educational Philosophy and Theory, 33(2), 245-256. Dostupné z http://dx.doi.org/10.1111/j.1469-5812.2001.tb00266.x

- Stables, A. (2006). Language and meaning in environmental education: an overview. Environmental Education Research. 12(3-4), 327-334. Dostupné z http://dx.doi.org/10.1080/13504620600942782

- Stables, A., Scott, W. (1999). Environmental Education and the Discourses of Humanist Modernity: redefining critical environmental literacy. Educational Philosophy and Theory, 31(2), 145-155. Dostupné $z$ http://dx.doi.org/10.1111/j.14695812.1999.tb00381.x

- St Maurice, H. (2006). Nature's nature: ideas of nature in curricula for environmental education. Environmental Education Research, 12(3-4), 301-308. Dostupné z http://dx.doi.org/10.1080/13504620600942725

- Stevenson, R., B., Brody, M., Dillon, J., Walls, E.J. (Ed.). (2013). International handbook of research on environmental education. 1st pub. New York: American Educational Research Association.

- Strife, S. (2010). Reflecting on Environmental Education: Where Is Our Place in the Green Movement? The Journal of Environmental Education, 179-191. Dostupné $\mathrm{z}$ http://dx.doi.org/10.1080/00958960903295233 
- Strouhal, M. (2013). Teorie výchovy. K vybraným problémům a perspektivám jedné pedagogické disciplíny. Praha : Grada Publishing.

- Svoboda, J. (2009). Kompletní návod k vytvoření Ekozahrady a rodového statku. Praha: Smart Press.

- Šmajs, J. (2007). Potřebujeme filosofii přežití? Úvahy o filosofii, kultuře, poznání, vzděláním řeči a popularizací vědy. Brno.

- Šmajs, J. (2013). Společenské vědy a jejich nové úkoly. Listy. Dostupné z http:// www.listy.cz/archiv.php?cislo $=132 \&$ clanek $=021362$.

- Štverák, V., (1999). Obecná a srovnávací pedagogika, Praha:Karolinum.

- Vladyková, L. (2015). The Philosophy of Ecology as a Specific and Direct Method of Ecological and Humanistic Research and Management. Envigogika, 10(4), 1-9. Dostupné z http://dx.doi.org/10.14712/18023061.498

- Vystrčil Marková, P., Horká H. (2013). Subjektivní teorie učitele o biofilní orientaci vzdělávání: ověřování výzkumného nástroje. In Švec V., Bradová J. (et.al.), Učitel $v$ teorii a praxi. Brno: Masarykova univerzita. Dostupné z http://katedry.ped.muni.cz/pedagogika/ucitel-v-teorii-a-praxi

- Walker K. (1997). Challenging Critical Theory in Environmental Education. Environmental Education Research, 3(2), 155-162. Dostupné z http://dx.doi.org/10.1080/1350462970030204

- Walker, K. (1997). Environmental education and the school curriculum: The need for a coherent curriculum theory. International Research in Geographical and Environmental Education, 6(3), 252-255. Dostupné z http://dx.doi.org/10.1080/10382046.1997.9965054

- Walker, K. (2006). Doing research in environmental education: touchstone theory and shaking things up. Environmental Education Research, 12(3-4), 391-401. Dostupné z http://dx.doi.org/10.1080/1350462060079912

- Williams, D. R., Brown, J. D. (2012). Learning Gardens and Sustainability Education: Bringing Life to Schools and Schools to Life. New York: Routledge.

- Winter, D. N., Koger, S. M. (2009). Psychologie environmentálních problémů. Praha: Portál.

- Zelezny, L. C. (1999). Educational Interventions That Improve Environmental Behaviors: A Meta-Analysis. The Journal of Environmental Education, 31(1), 5-14. Dostupné z http://dx.doi.org/10.1080/00958969909598627

- Zich, F. (1996). Teorie středního dosahu. In Maříková, H., Petrusek, M., Vodáková, A., a kol. Velký sociologický slovník, s 1313. 


\section{PŘÍLOHY}

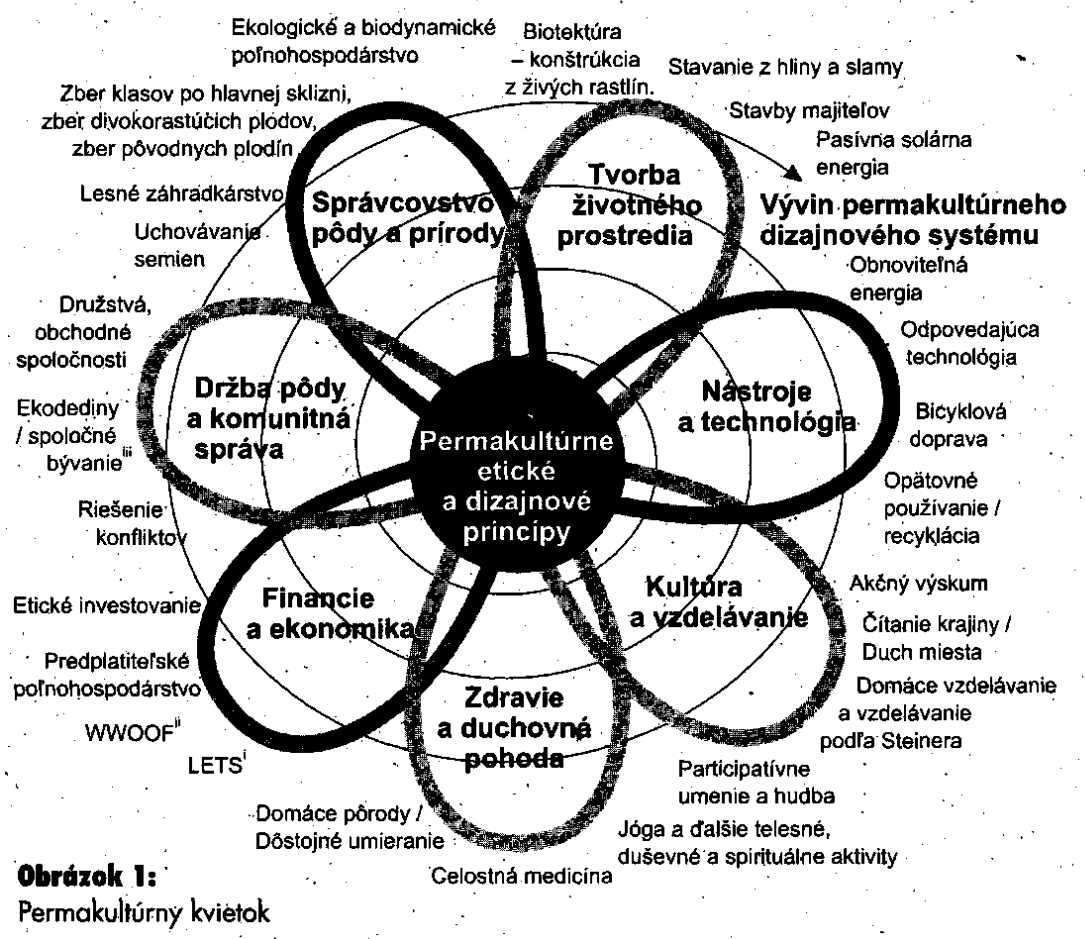

Obrázek 1: Permakulturní kvítek podle Holmgrena (Holmgren 2006 in Jirsová 2014: 11). 


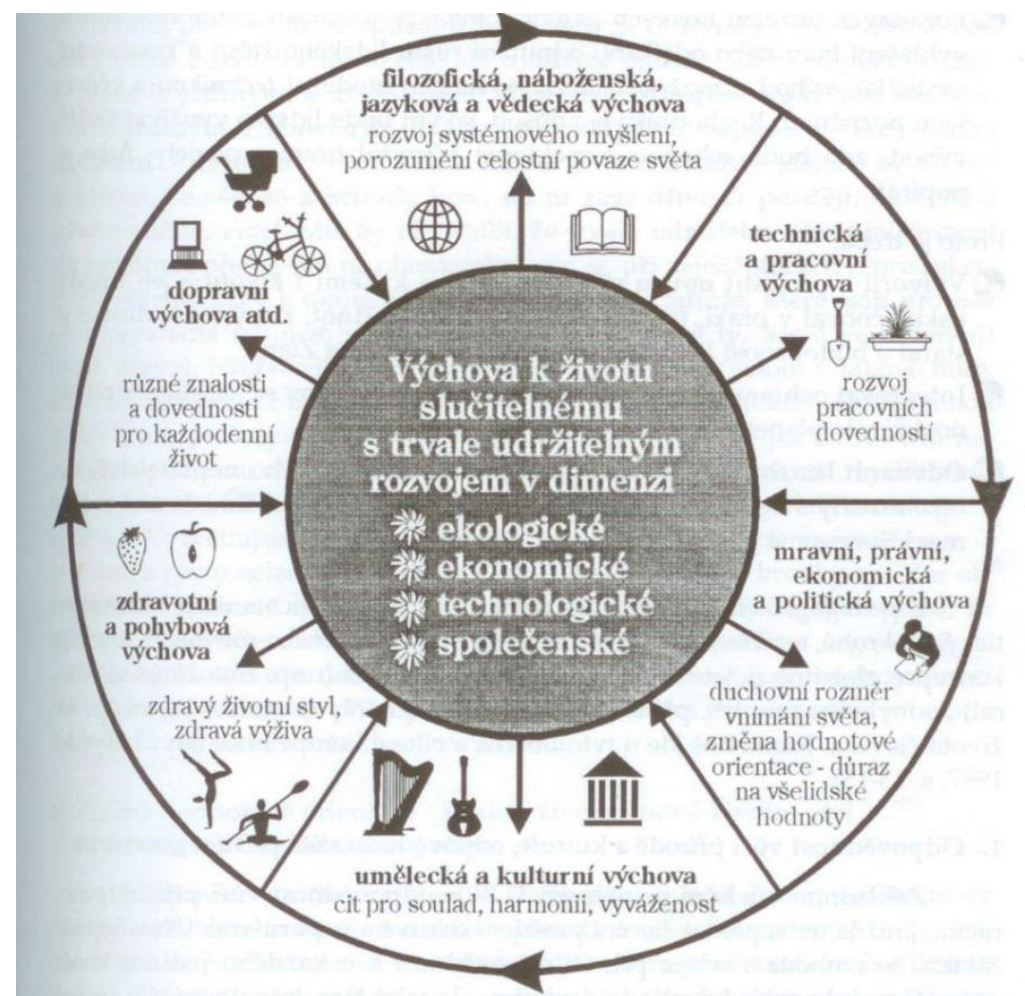

Obr. 2: Obsah globálni vúchovy - základni vazby a vztahy

Obrázek 2. Obsah globální výchovy podle H. Horké (Horká 2000: 57) 


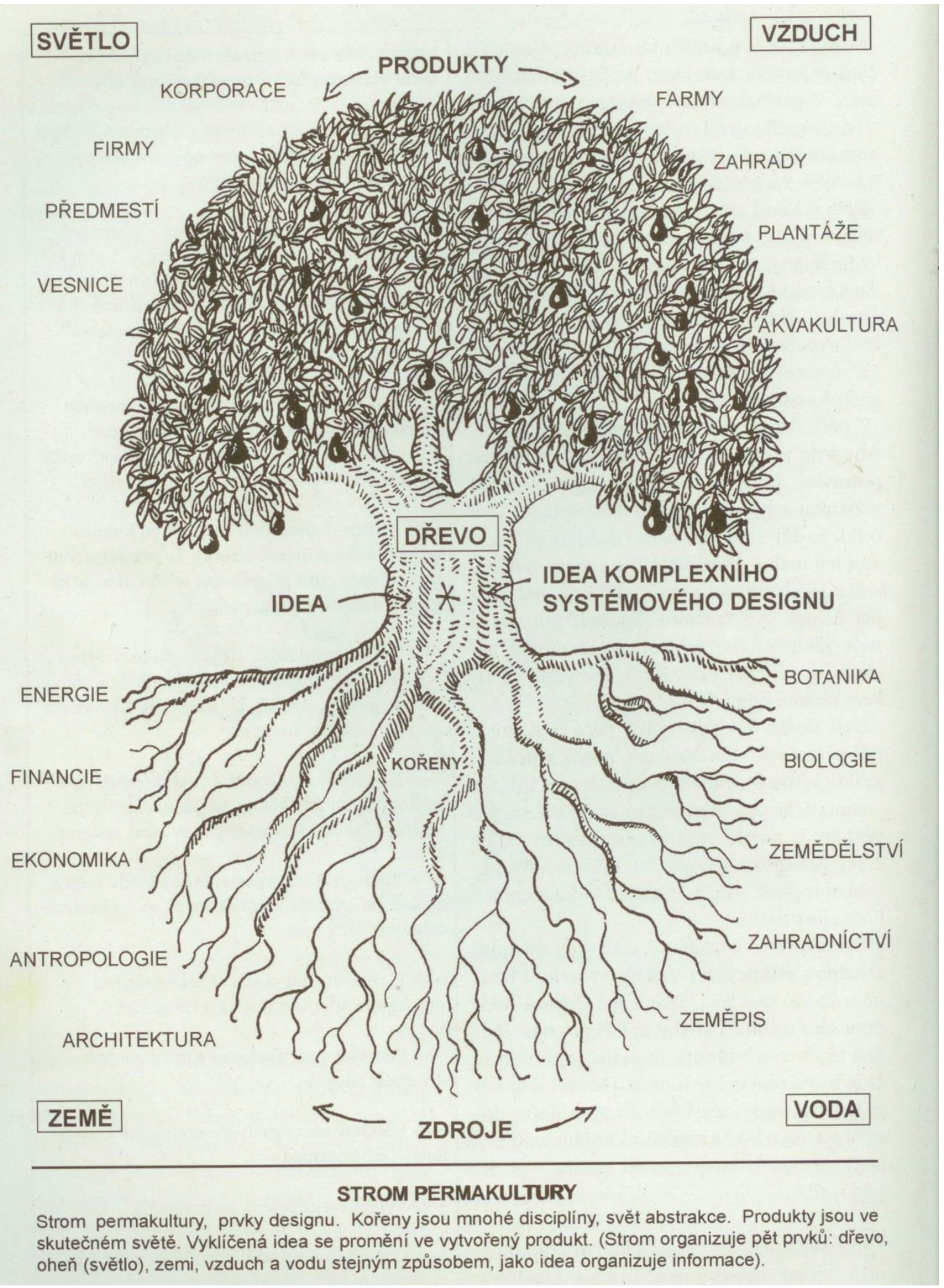

Obrázek 3. Strom permakultury, schéma komplexního systémového přístupu podle Mollisona (2012: 4) 
Mgr. Monika Janáková je studentkou doktorského studia Pedagogické fakulty MU. Tématem její disertační práce je permakultura v kontextu environmentální výchovy (EV) a také využití zvířat v edukačním procesu, především koní. Vedle EV patři $k$ oblasti jejího odborného zájmu také české avantgardní umění v sakrálním prostoru (vystudovala dějiny umění na FFMU v Brně). 